\title{
Time-dependent in situ measurement of atmospheric corrosion rates of duplex stainless steel wires
}

\author{
Cem Örnek $\mathbb{D}^{1,2}$, Fabien Léonard ${ }^{3}$, Samuel A. McDonald $\mathbb{D}^{4}$, Anuj Prajapati $\mathbb{D}^{5}$, Philip J. Withers ${ }^{4}$ and Dirk L. Engelberg $^{6}$
}

Corrosion rates of strained grade UNS S32202 (2202) and UNS S32205 (2205) duplex stainless steel wires have been measured, in situ, using time-lapse X-ray computed tomography. Exposures to chloride-containing $\left(\mathrm{MgCl}_{2}\right)$ atmospheric environments at $50{ }^{\circ} \mathrm{C}$ (12-15 $\mathrm{M} \mathrm{Cl}^{-}$and $\mathrm{pH} \sim 5$ ) with different mechanical elastic and elastic/plastic loads were carried out over a period of 21 months. The corrosion rates for grade 2202 increased over time, showing selective dissolution with shallow corrosion sites, coalescing along the surface of the wire. Corrosion rates of grade 2205 decreased over time, showing both selective and pitting corrosion with more localised attack, growing preferentially in depth. The nucleation of stress corrosion cracking was observed in both wires.

npj Materials Degradation (2018)2:10; doi:10.1038/s41529-018-0030-9

\section{INTRODUCTION}

A better understanding of corrosion kinetics with exposure to atmospheric conditions has vital importance for assessing the application of duplex stainless steels (DSS) for structural components. ${ }^{1-6}$ The UK's intermediate-level radioactive nuclear waste (ILW) is currently stored in grade AISI 316L/304L austenitic stainless steel containers in above-ground storage facilities, until a deep-underground geological disposal facility becomes available. $^{5}$ Grade 2205 DSS has been proposed as a replacement option for both austenitic grades due to its improved corrosion and stress corrosion cracking (SCC) performance, and nowadays leaner alloyed duplex grades, such as 2101 or 2202, are also being considered. ${ }^{5}$

The surface of waste containers held in stores may experience the deposition of chloride-bearing particulates from sea-salt aerosols and/or industrial pollution, which may lead to localised corrosion. $^{7-16}$ A thorough understanding of localised corrosion and the nucleation of SCC under atmospheric exposure has significant importance for the use of DSS as candidate container materials. Quantitative assessment of the early stages of degradation is therefore required to be able to determine the life-time performance of structural components. ${ }^{17,18}$ State-of-theart characterisation techniques, such as X-ray computed tomography (X-ray CT), can provide non-destructive, in situ, information about the location, extent, and kinetics of damage evolution., ${ }^{77-22}$ Initial stages of localised corrosion and SCC can be visualised and quantified, with data providing the framework for life-time prediction models. ${ }^{17,18,22}$

Corrosion characterisation so far has been limited to corrosion rate (CR) assessments derived from either electrochemical methods or weight loss measurements, which has become routine practice in quantifying aqueous CRs. However, the 'classic'
CRs give no information about the morphology and progress of corrosion and may not be useful for cases in which localised corrosion is the concern. Stainless steels are susceptible to localised corrosion, requiring the need for a more appropriate approach to quantifying the local CR. Moreover, in atmospheric conditions, corrosion is further localised and often incomparable with aqueous corrosion scenarios. Atmospheric corrosion is a long-term concern and requires in situ measurement of corrosion propagation. Corrosion data obtained from ex situ measurements may not reflect in-operando conditions, and therefore, in situ, corrosion assessments are needed. This shortcoming can be coped with the X-ray CT approach, being useful in measuring, in situ, the atmospheric corrosion behaviour and visualising the corrosion progress in 3D space.

Atmospheric corrosion of DSSs has been studied, but most data have limited relevance for ILW storage applications since aggressive exposure conditions have typically been chosen as test environments. ${ }^{1-3,23-27}$ Most of the chosen chloride deposition densities were 1000's of $\mu \mathrm{g}$ to 100 's of $\mathrm{mg}$ per $\mathrm{cm}^{2}$, being too aggressive to reflect real exposure conditions for ILW containers in storage facilities maintained through the use of a filtered ventilation system. Therefore, a more systematic investigation in environments with low-chloride deposition densities is needed to assess the long-term structural integrity without the overestimation of unlikely events of chloride contamination. The atmospheric corrosion performance of DSS has been studied as a function of strain, stress, and deposition density, and so far, a good understanding of the relationship of ferrite and austenite in DSS microstructures has been established. ${ }^{28-37}$ However, CRs and SCC growth rates, in particular under atmospheric exposure conditions, have not been reported yet.

The work reported in this paper compares the corrosion performance of lean DSS grade 2202 and standard grade 2205

\footnotetext{
${ }^{1}$ Division of Surface and Corrosion Science, School of Chemical Science and Engineering, KTH Royal Institute of Technology, Drottning Kristinas Väg. 51, 10044 Stockholm, Sweden; ${ }^{2}$ Department of Corrosion in Energy and Process Industry, Swerea KIMAB, Isafjordsgatan 28A, 16440 Kista, Sweden; ${ }^{3}$ BAM Federal Institute for Materials Research and Testing, Unter den Eichen, 8712205 Berlin, Germany; ${ }^{4}$ Manchester X-ray Imaging Facility, School of Materials, The University of Manchester, Sackville Street, Manchester M13 9PL, United Kingdom; ${ }^{5}$ Department of Metallurgical and Materials Engineering, Visvesvaraya National Institute of Technology, South Ambazari Road, Abhyankar Nagar, Nagpur,

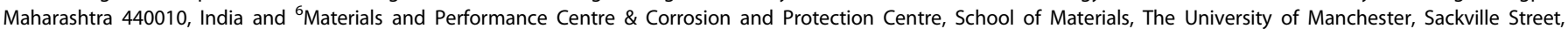
Manchester M13 9PL, United Kingdom

Correspondence: Cem Örnek (ornek@kth.se)
}

Received: 12 November 2017 Revised: 12 January 2018 Accepted: 22 January 2018

Published online: 07 March 2018 

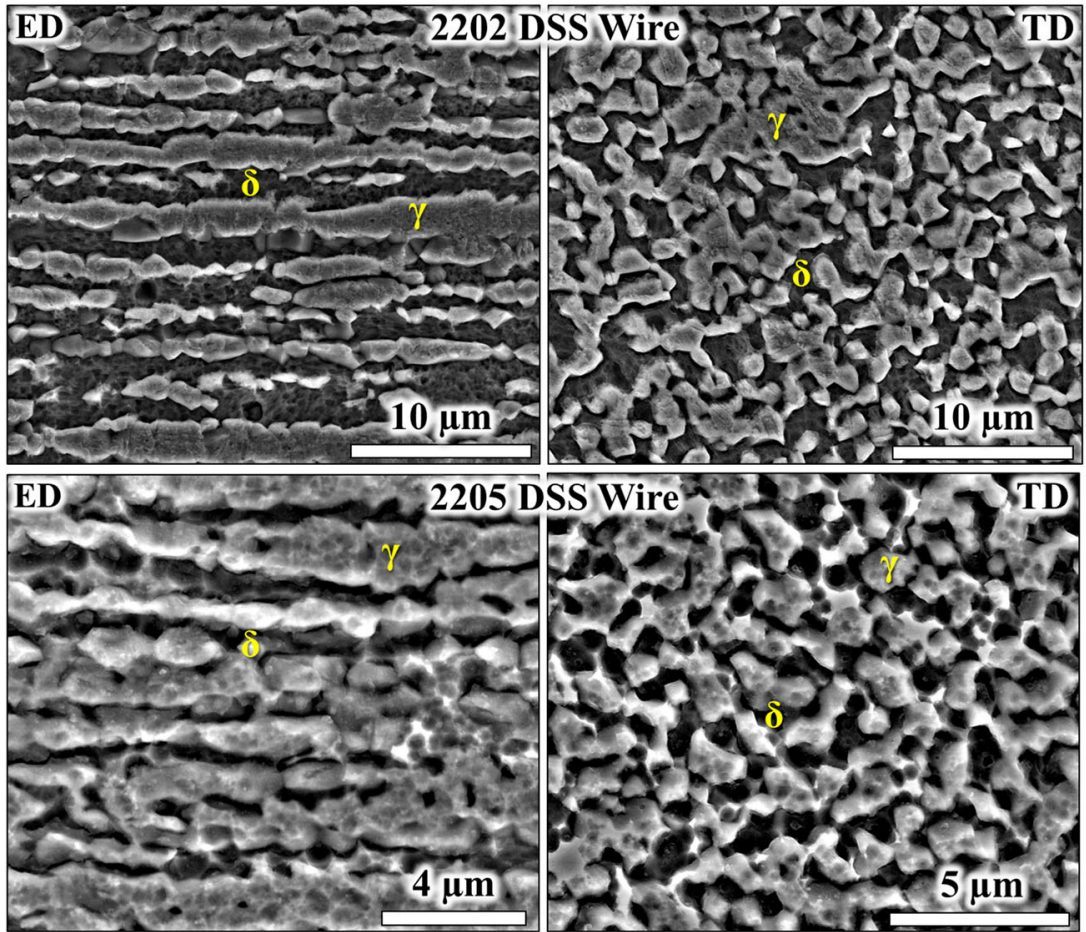

Fig. 1 SE-SEM images of the microstructure of 2202 and 2205 DSS wires for cross-sections with austenite $(\gamma)$ and ferrite $(\delta)$ marked, containing the extrusion direction (ED $\leftrightarrow$ ) and the transverse direction (TD↔) after $\mathrm{KOH}$ etching

wires with exposure to chloride-containing atmospheric environment. The wires were contaminated with $\mathrm{MgCl}_{2}$ aqueous solution and exposed to $50{ }^{\circ} \mathrm{C}$ and $30 \%$ relative humidity (RH), and timedependent, measurements of CRs obtained using time-lapse, in situ X-ray CT observations.

\section{RESULTS}

The microstructures of both DSS wires are shown in Fig. 1. Both grades had a similar microstructural appearance, with austenite and ferrite grains elongated along the drawing direction, as shown in Fig. 1 . The phase ratio of ferrite to austenite was approximately 50:50 determined from optical micrographs, with fine grain structures containing $\mu \mathrm{m}$-sized grains (ASTM grain size no. G14.0). Both grades, 2202 and 2205 DSS, are representative of drawn and subsequently recrystallised wire microstructures. No secondary phases were observed in the microstructures.

\section{Corrosion tests-Grade 2202 DSS}

The atmospheric corrosion attack on lean 2202 DSS wire is shown via the reconstructed X-ray $C T$ data in Fig. 2. After 83 days, large corrosion patches were observed, visible in Fig. 2a. Corrosion has initiated at least at three discrete sites. The depth and morphology of the corroded regions are represented by the segmented volumes (red), shown in Fig. $2 \mathrm{~b}$, d. The corrosion damage reached a maximum depth of $\approx 45 \mu \mathrm{m}$. The dissolution of the microstructure during atmospheric corrosion seemed to spread preferentially along the outer surface rather than in depth. Pitting corrosion seemed to have been less favoured apparent from minor localised forms of cavities observed, indicating corrosion attack occurred primarily by selective dissolution. An increase of the extent of surface corrosion (superficial attack along the wire surface with less propensity to penetration) is apparent in Fig. 2c, $\mathrm{d}$ with exposure for 177 days, in the form of shallow surface attack. After 18 months of exposure, the corrosion attack had spread across the full length of the wire, shown in Fig. 2 e.

\section{Corrosion tests-Grade 2205 DSS}

The corrosion morphology of the 2205-2 DSS wire (0.65 YS) is shown in Fig. 3. After exposure for 146 days, discrete localised corrosion sites (in the form of pitting) and atmospherically chloride-induced stress corrosion cracking (AISCC) were observed. Figure $3 a-e$ shows the presence of more discrete corrosion sites compared to observations on the grade 2202 wire (Fig. 2). The discrete sites have the appearance of corrosion pits, with an SCC crack observed inside one of these sites, shown in Fig. 3b-e. This crack was located at the inner pit wall, which is clearly noticeable from the dark contrast in Fig. 3c,d. The maximum crack length was about $80-100 \mu \mathrm{m}$, with a bifurcated appearance, indicating chloride-induced SCC. The latter is typical for stainless steels in chloride environments and has often been explained by the adsorption-induced dislocation-emission mechanism for SCC. ${ }^{38} \mathrm{~A}$ region showing a different level of grey scale contrast (elliptical shape) was observed at the bottom of the pit, adjacent to the crack in Fig. 3c, d. This contrast indicates selective dissolution of the ferrite or de-alloying, ${ }^{38}$ resulting in a partial loss of material, leading to a different level of X-ray attenuation (represented by the grey scale) in this region. Localised corrosion typically promotes initiation of SCC, commonly observed in stainless steels. ${ }^{38}$ Selective dissolution of the ferrite phase may be more likely in DSS due to the lower corrosion potential of the ferrite than that of the austenite in chloride-containing environments. ${ }^{36,39-43}$ However, selective attack of the austenite may also be possible if the oxidising power of the electrolyte is sufficiently high, where the ferrite remains passive. ${ }^{39-42}$

The extent of surface corrosion and the dissolved volume slightly increased with exposure time, as shown in Fig. 3f, g. A new corrosion site was observed after 234 days of exposure (Fig. 3f), which had grown in size and depth after 676 days, highlighted in Fig. 3g. The initiation of new corrosion sites seemed to be favoured in this sample, rather than the growth of existing corrosion sites, which can clearly be seen by the number of small, discrete corrosion sites in Fig. $3 g$. 

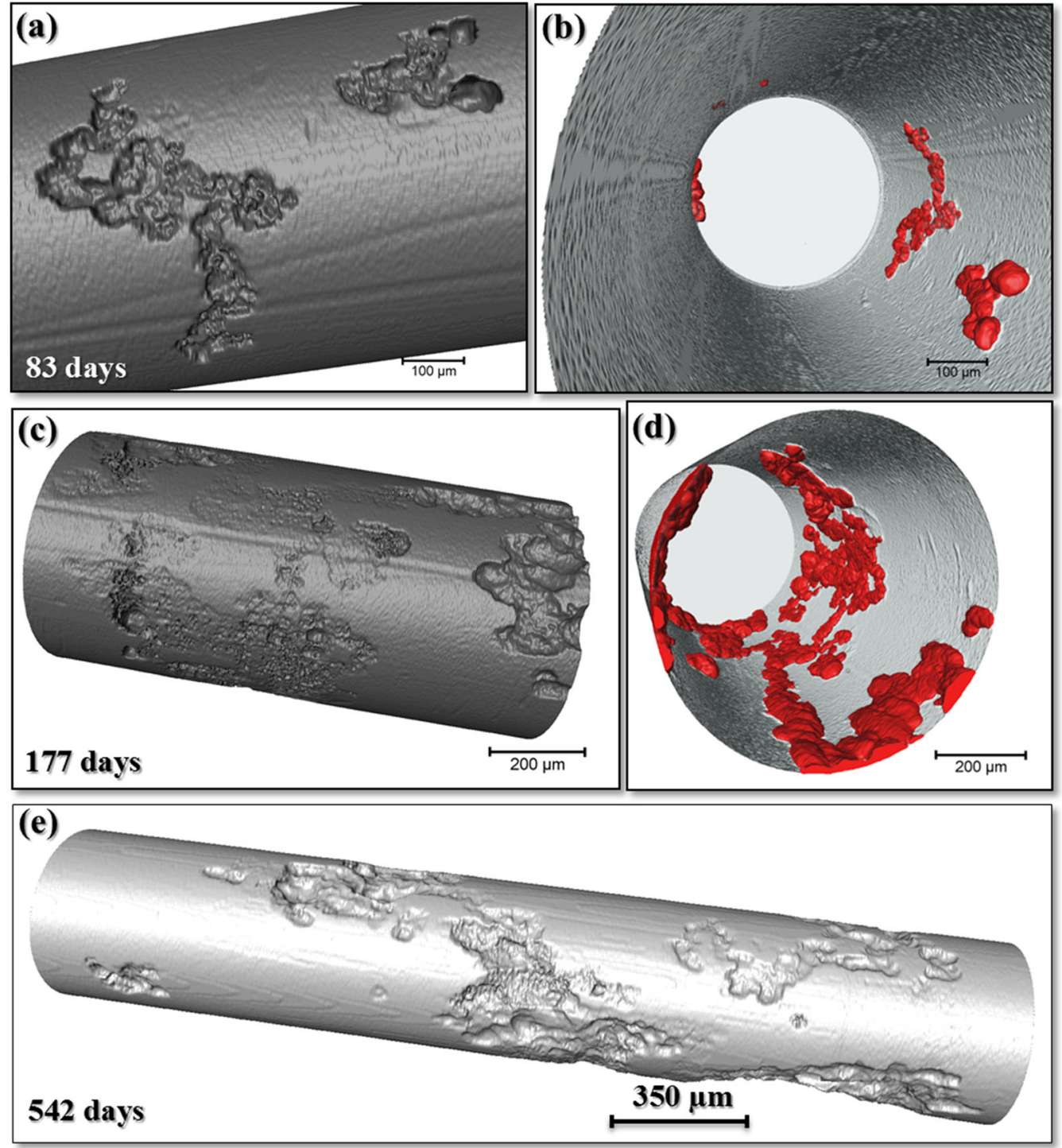

Fig. 2 3D visualisations of the reconstructed volume of lean 2202-1 (YS) DSS showing a, b the corrosion morphology after 83 days of exposure, $\mathbf{c}$, $\mathbf{d}$ after 177 exposure days, and $\mathbf{e}$ after 542 days. In $\mathbf{b}$ and $\mathbf{d}$ the material lost by corrosion has been segmented (red)

The corrosion morphology of the 2205-3 DSS wire (1.2 YS) after 86 days of exposure is shown in Fig. $4 a-c$. Several discrete corrosion sites are evident in the form of corrosion pits. The number of localised corrosion sites increased with exposure time, and most of the existing pits also appear to grow over time. Corrosion seems to have propagated along the outer surface in the direction of the extrusion axis, resulting in an undercut appearance (Fig. 4f). A number of smaller pits were also present after 524 days of exposure, as evident in Fig. $4 \mathrm{~h}-\mathrm{i}$.

The corrosion morphology of the $2205-4$ (1\% strain) DSS wire is shown in Fig. 5. Several discrete, elongated corrosion sites, resembling a filiform corrosion-like appearance are evident in Fig. $5 a-e$ after 84 days of exposure. Such attack is typical for crevice corrosion, which occurs in confined spaced to which the access of oxygen is limited or less than the surrounding electrolyte, causing shallow, but wide metal dissolution. ${ }^{44,45}$ The corrosion site in Fig. 5 a grew by $\approx 50 \%$ in volume after 524 days of exposure, and seemed to propagate in depth rather than in width, as shown in Fig. 5f, g, k. The elongated corrosion site, in contrast, did not seem to propagate further, shown in Fig. 5h, i, l. Corrosion propagation may have been facilitated by the corrosion products formed, covering the surface area of the wire, visible as light grey in Fig. 5h. The crevice chemistry is typically more severe than in corrosion pits, manifested by lower $\mathrm{pH}$. Both corrosion sites grew preferentially in depth, supporting this statement.

\section{Corrosion propagation}

The change in corroded area, corroded volume, maximum corrosion depth, and the corrosion penetration rate over time is summarised in Figs. 6, 7. The data shown in Fig. 6 are given as normalised area and normalised volume to compensate for slight differences in the scanned regions and volumes during the timelapse investigation. Atmospheric corrosion growth on the lean 2202 DSS occurred along the wire surface rather than in depth, whereas corrosion on all 2205 duplex wires seemed to grow preferentially in depth. There seemed to be a linear surface corrosion attack and metal volume loss with time for both grades. However, the lean wire was seen to be more susceptible to corrosion than the conventional 2205 duplex wire. The change in surface corrosion area, corrosion volume, and corrosion depth observed on 2202 DSS was more pronounced than those seen on 2205 duplex wires. The maximum corrosion depth on grade 2205 decreased with the increase of applied strain (Fig. 7 (left)). The 

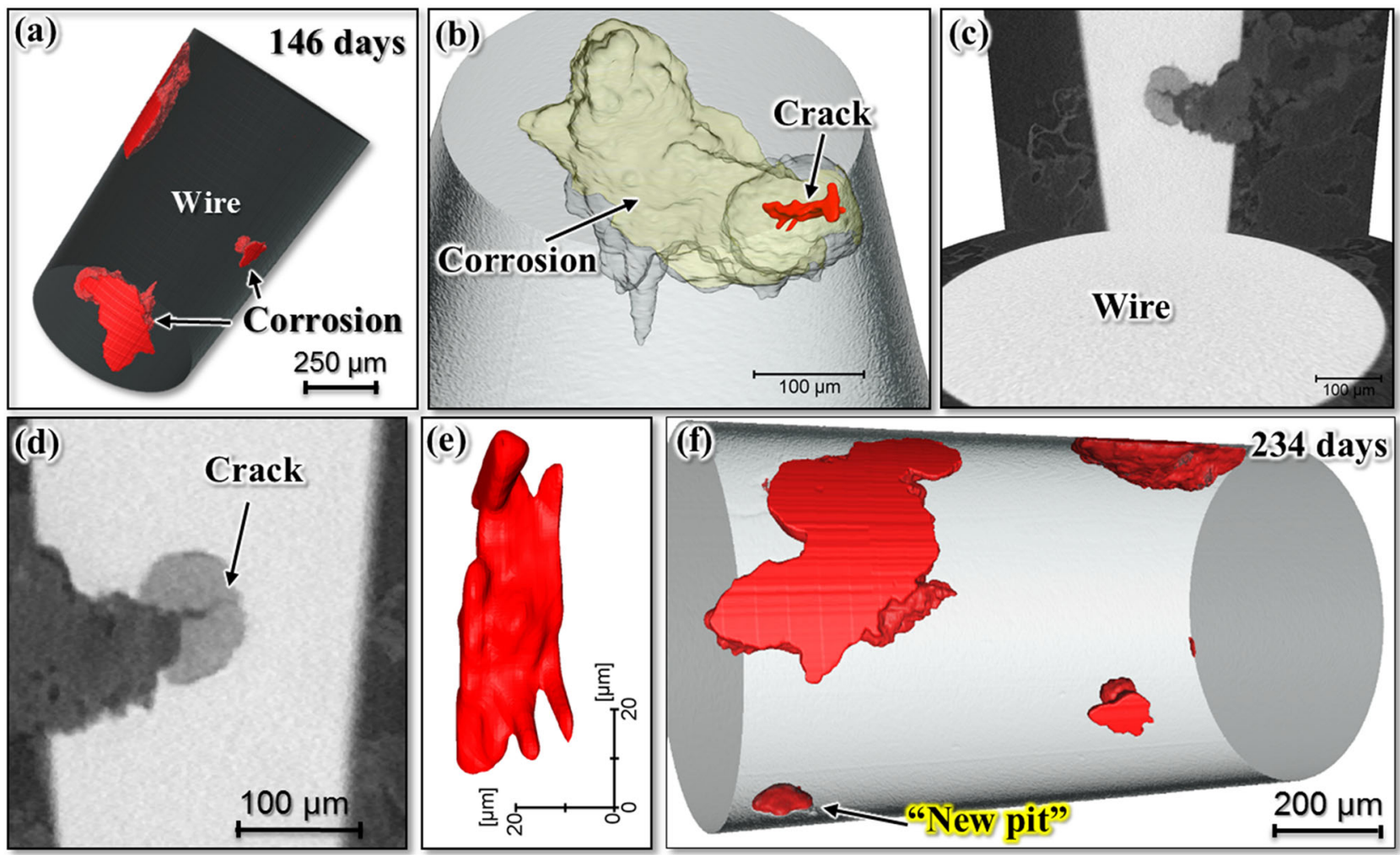

(g)

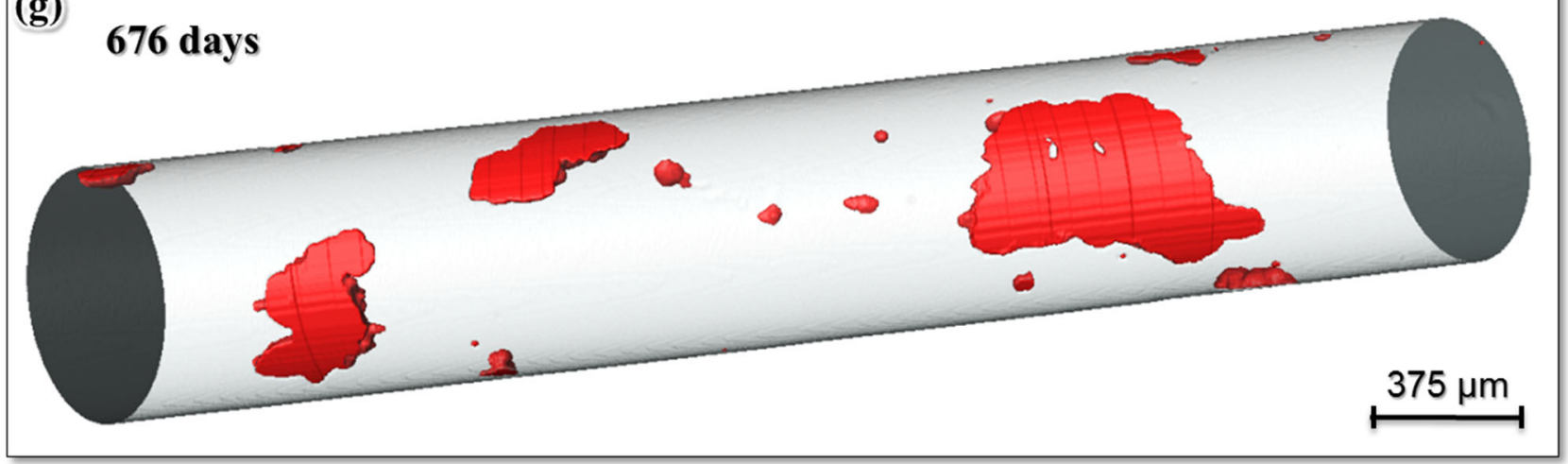

Fig. 3 3D visualisations of the reconstructed volume of 2205-2 DSS ( 0.65 YS) showing a the corrosion morphology after 146 days of exposure, b the large corrosion site in a segmented in a semi-transparent view with the crack nuclei highlighted in red in c, $\mathbf{d}$ virtual cross-sections showing the crack nuclei in $\mathbf{b}$ from different view angles, e segmented shape of the crack nuclei in red, and $\mathbf{f}$ corrosion morphology after exposure for 234 days, and $\mathbf{g}$ after 676 days. Note the dark grey scale level around the crack in $\mathbf{c}$ and $\mathbf{d}$ is most-likely due to selective dissolution of the ferrite at the pit bottom. The material loss has been segmented (red)

penetration rates for both grades decayed over time and were of similar magnitudes (Fig. 7 (right)). The corrosion penetration rate of grade 2205, furthermore, seemed to decrease with the increase of strain. Strain seemed to be beneficial for grade 2205, imparting an improvement of corrosion resistance.

\section{Corrosion rates}

The development of the surface corroded areas and their corresponding total dissolved volumes for all four wires over time is summarised in Fig. 6 . The resulting CRs in Fig. 8 are calculated from the measured total volume loss, with Fig. 8 (left) showing the CRs normalised to the surface area of the wire (approach (i)), and Fig. 8 (right) an estimation of the CR normalised to the corroded surface area of the wire (approach (ii)). The difference between both CRs captures the heterogeneity of corrosion attack, with approach (i) in Fig. 8 (left) including areas in the CR measurement that are not corroded.

For the grade 2202 sample, the extent of corrosion along the surface increased significantly with exposure time compared to all grade 2205 wires. This was also in-line with the total volume loss due to corrosion attack, showing the highest dissolved volume of all the investigated wires. After exposure for 6 months, the mean $C R$ reached $\approx 7 \mu \mathrm{m} /$ year, with a further slight increase over time, levelling off at $\approx 8 \mu \mathrm{m} /$ year after 524 days of exposure. If only the corroded sites are considered (Fig. 8 (right)), CRs of up to $10 \mu \mathrm{m} /$ year are obtained.

For all the 2205 wire samples, the corroded area and volume increase almost linearly with exposure time (Fig. 6), albeit showing large differences in CRs for each wire. The mean CR of the 2205 duplex wires was initially in the range of 2-6 $\mu \mathrm{m} /$ year. The mean $\mathrm{CR}$, however, decreased for all grade 2205 samples over time reaching values of $\approx 0.5-1.5 \mu \mathrm{m} /$ year, as summarised in Fig. 8 (left). 

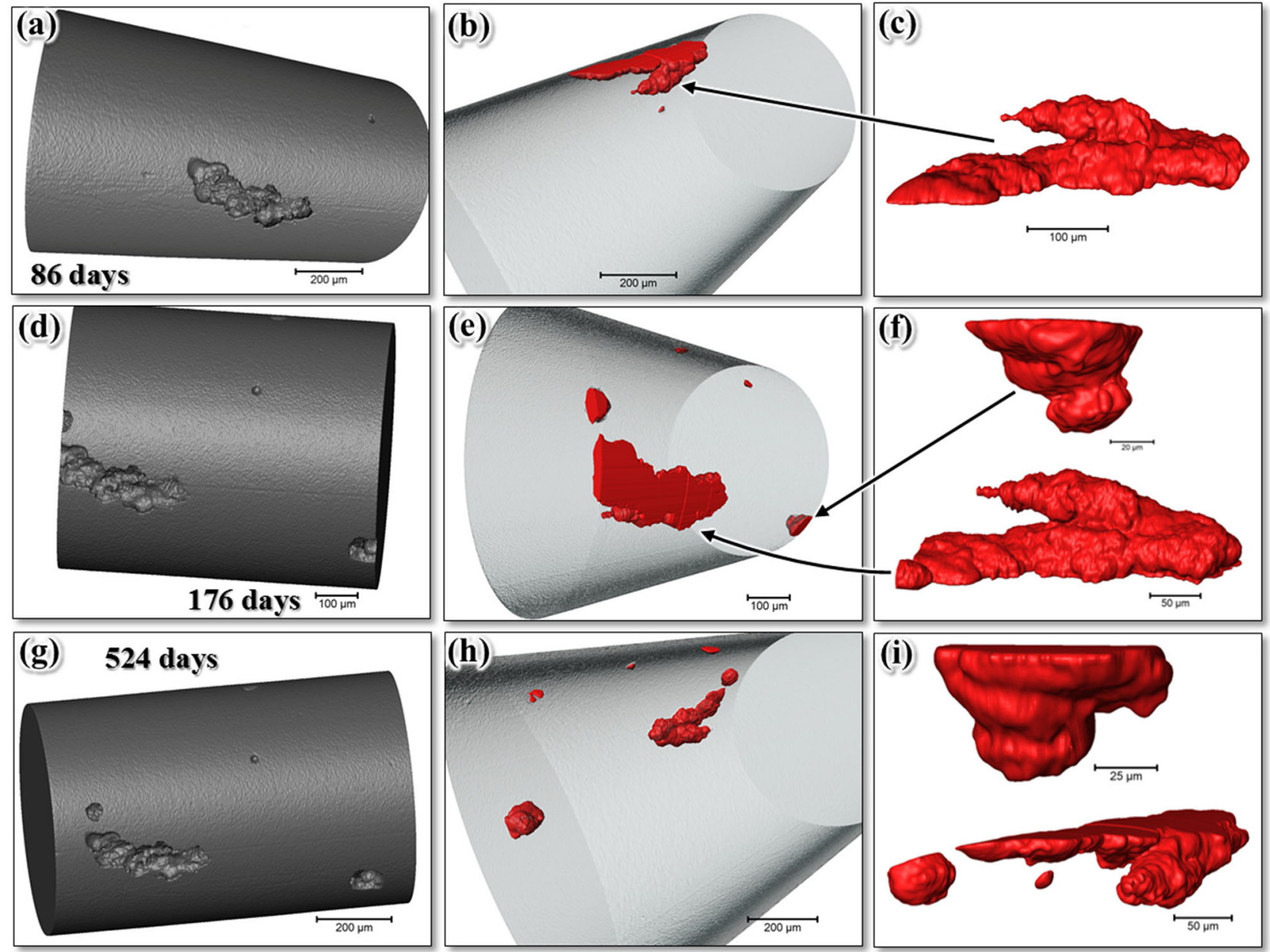

Fig. 4 3D visualisations of the reconstructed volume of grade 2205-3 (1.2 YS) DSS, showing $\mathbf{a}, \mathbf{b}$, $\mathbf{c}$ the corrosion morphology after 86 days of exposure, $\mathbf{d}, \mathbf{f}$ after 176 days, and $\mathbf{g}, \mathbf{h}$, $\mathbf{i}$ after 524 days of exposure. Note the new corrosion pits formed after 176 days which slightly grew after 524 days. The material loss has been segmented (red)

However, if the CR was only calculated with respect to the corroded surface areas, the highly localised nature of the corrosion attack becomes obvious, resulting in initial rates of up to $40 \mu \mathrm{m} /$ year, decreasing over time to values of $5-10 \mu \mathrm{m} /$ year (Fig. 8). In general, the total corroded volumes were far smaller for all the grade 2205 wires, compared to that for the 2202 wire sample. It should be noted that the mean CR does not reflect the growth direction of corrosion and gives indication about the corrosion propagation only.

\section{Post-mortem analysis of the corrosion morphologies}

A general overview of corroded sites for the grade 2202 wire after 541 days of exposure is shown in Fig. 9a in accordance with the $X$ ray $C T$ in Fig. 2. The same regions scanned by $X$-ray $C T$ were imaged in the scanning electron microscope (SEM), and a good correlation was obtained. SEM analyses revealed only a surface view of the corroded wire, and therefore, the volumetric information such as crack propagation towards the wire interior could not be correlated. However, information from the wire surface with nanometre spatial resolution was obtained and surface cracks not detected by X-ray CT could be imaged in the SEM. Both X-ray CT and SEM examinations revealed complementary information in assessing the extent of SCC.

Large corroded patches were observed in the 2202 wire as shown in Fig. 9a. A number of local corrosion sites are evident (Fig. 9b), most likely formed by selective dissolution of the ferrite
(Fig. 9c). ${ }^{29,33,36}$ Regions containing small, narrow crack-like fissures were also observed (Fig. 9c, e) having dimensions of a few micrometres which were below the resolution limit of the current CT images. A number of slightly larger cracks (tens of micrometres) are also evident, as highlighted in Fig. 9d. Some of these cracks appeared to have not entirely propagated through grains, as shown in Fig. 9(e). It is unclear when these cracks have formed since these were not apparent in x-ray CT data shown in Fig. 2. The longest crack observed by SEM had a length of $\approx 100 \mu \mathrm{m}$ across the surface.

The corrosion morphology of the exposed 2205-2 wire is shown in Fig. 10. A few discrete local corrosion sites with sizes of 20$150 \mu \mathrm{m}$ in diameter are apparent, as shown in Fig. 10a. These sites have deep, pit-type morphologies, some with evidence of undercutting which are reminiscent of lacy cover pitting (Fig. 10b). Some shallow pits (Fig. 10c) are also present. It seems that selective corrosion of the ferrite phase has occurred within these pits. Several micro-cracks, adjacent to local corrosion sites are evident (Fig. 10d). SCC was observed with a maximum crack length of $80-100 \mu \mathrm{m}$ across the surface, but no cracks were seen adjacent to small, shallow corrosion pits. Unlike for grade 2202, long micro-cracks with wide crack openings were found at the centre of one of the corrosion sites (Fig. 10e. Surface corrosion seems to be less favoured on strained grade 2205 (1.2 yield) than on grade 2202 samples. However, grade 2205 seemed to be more susceptible to SCC. Moreover, filiform-like corrosion morphology 

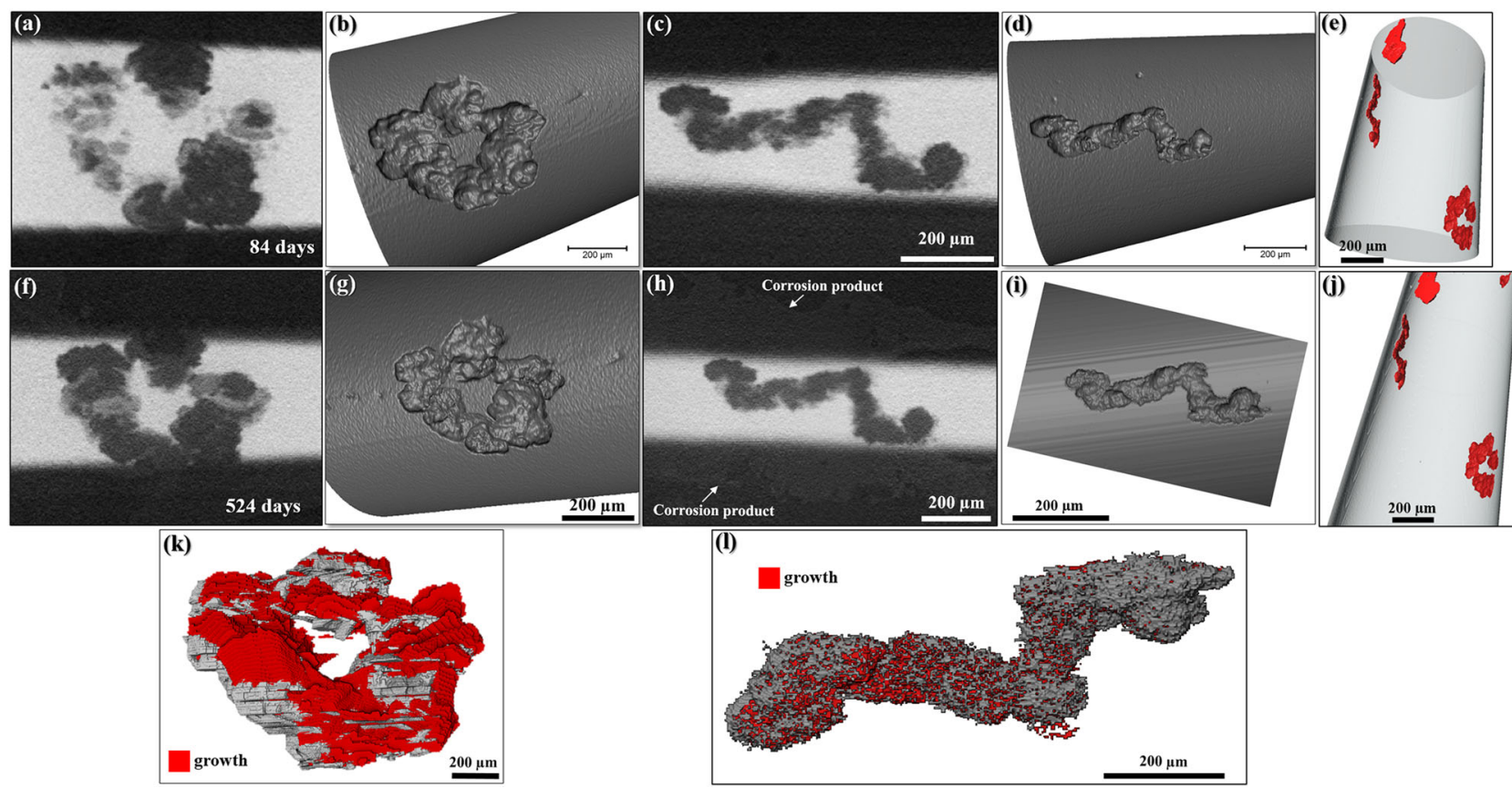

Fig. 5 3D visualisations of the reconstructed volume of grade 2205-4 DSS (1\%), showing the corrosion morphology a, b, c, d, e after exposure for 84 days and $\mathbf{f}, \mathbf{g}, \mathbf{h}, \mathbf{i}, \mathbf{j}$ after 524 days. Note the corrosion products formed above the wire shown in $\mathbf{h}$. Corrosion growth (in red) occurred between 84 and 524 days of both corrosion sites are shown in $\mathbf{k}$ and $\mathbf{I}$

with shallow corrosion attack was observed, shown in Fig. 10(f), with numerous intragranular corrosion sites present (Fig. 10i).

The general overview of the corrosion morphology of the 2205-3 DSS wire is shown in Fig. 11. Similar to the other 2205 duplex wire, discrete local corrosion sites in the form of corrosion pits were seen. SCC was also observed with a crack length of maximum $100 \mu \mathrm{m}$.

The corrosion morphology of the 2205-4 wire is shown in Fig. 12 , with several local corrosion sites and a crack running along the axis of the wire. This crack was found to run along most of the length of wire with convoluted morphology, as shown in Fig. 12c. A few regions with small fissures adjacent to localised corrosion sites are also evident, with a typical example shown in Fig. 12b, d, e. Small pits and intergranular corrosion was seen in certain regions Fig. 12d, and most of the localised corrosion sites were shallow, as shown in Fig. 12e. A higher magnification view also shows that selective corrosion plays a major part in the corrosion attack, evident by the observed grain facets in Fig. 12f. The corrosion attack supports previous observations of local corrosion. However, it is not clear how and when the observed crack, which had maximum dimensions in excess of $1 \mathrm{~mm}$ across the wire surface, was formed. Some grains, most-likely austenite grains, seem to have cracked, as can be seen in Fig. $12 \mathrm{f}$.

\section{DISCUSSION}

Without the presence of strong oxidising agents, the ferritic phase is typically selectively dissolved in grade 2205 DSS with exposure to chloride-containing environments, due to its lower corrosion potential. ${ }^{33,35,36,41,42,46,47}$ Similar observations of selective attack on the ferrite phase have also been reported on lean DSS 2101 and 2202. ${ }^{2,48,49}$ In lean DSS 2202, the measured corrosion depthto-area ratio was low, indicating a strong tendency for repassivation of active corrosion sites. However, both the corroded area and volume for the lean 2202 wire were larger than for all the 2205 wires indicating lower corrosion resistance.

Corrosion into the 2205 microstructure advanced more in depth assuming pit-like morphologies, whereas in 2202 wire metal dissolution expanded laterally across the surface (Fig. 9 and Fig. 10). It is known that $5-6 \mathrm{M}$ of chloride is required for active pit growth in stainless steel. ${ }^{50}$ Under atmospheric exposure with $\mathrm{MgCl}_{2}$ close to the deliquescence humidity at $50^{\circ} \mathrm{C}$, chloride concentrations of 12-15 M exist, which was far above the chloride threshold level for local breakdown of stainless steels surface. ${ }^{1,2,51}$ Grade 2205 DSS is more resistant than 2202 DSS and, hence, the critical chloride concentration for passivity breakdown will be higher. However, when local breakdown of the passive layer of 2205 DSS occurs, the dissolution kinetics are higher since the anodic current is concentrated into a smaller area (large cathodeto-anode ratio), which will drive the metal to dissolve favourably in depth. This is the reason for the observation of pitting-like corrosion in 2205 DSS. In contrast, local breakdown on the lean 2202 wire occurs faster and, therefore, corrosion extended favourably along the surface of the wire. This example shows clearly the difference between atmospheric corrosion and aqueous corrosion.

The extent of surface corrosion vs. exposure time plotted in Fig. 6 (left) shows fast lateral expansion of corrosion with time, with the dissolved corrosion volume shown in Fig. 6 (right). There seemed to be approximately a linear relationship between the growths of the corroded volume, the expansion of the corroded surface area, and the exposure time, indicating a more dissolutiondriven process. The CR of grade 2202 also increased with exposure time, as shown in Fig. 8.

CRs of DSSs are usually lower than their austenitic counterparts in most corrosive media due to the synergy between the ferrite and austenite. ${ }^{52}$ It has been reported that the $\mathrm{Ni}$ content is critically important for pitting corrosion and associated corrosion behaviour, because it decreases the active dissolution rate of the metal. ${ }^{53,54}$ Thus, larger Ni contents can retard corrosion incubation time and improve the re-passivation kinetics of the stainless steel. ${ }^{53}$ The Ni content in 2202 DSS is low (max. 2.8 wt.\%), which may negatively affect the CR. Furthermore, the Mo content is also low in this lean DSS grade (max. 0.45 wt.\%), which is usually described to be responsible for improving the localised corrosion resistance of DSS microstructures. ${ }^{55,56}$ 

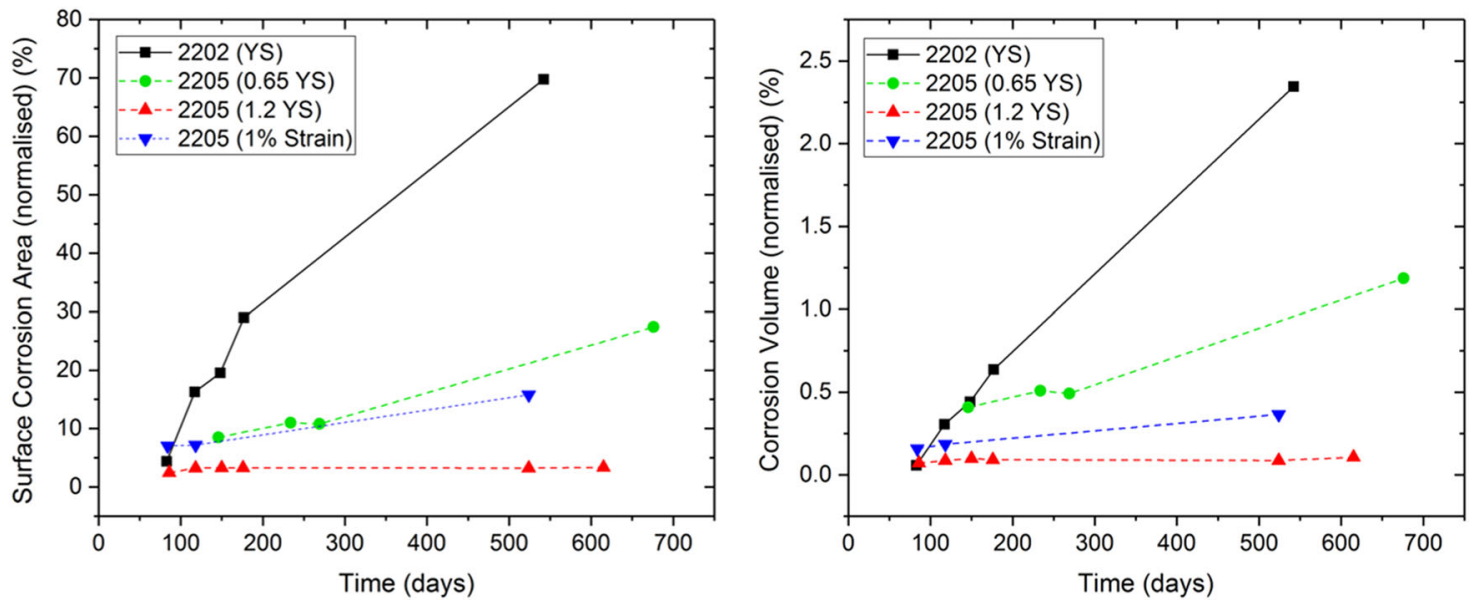

Fig. 6 Measured area of surface corrosion (left) and volume of corrosion (right) by X-ray CT over time for grade 2202 and 2205 DSS after exposure to magnesium chloride at $50^{\circ} \mathrm{C}$ and $30 \% \mathrm{RH}$
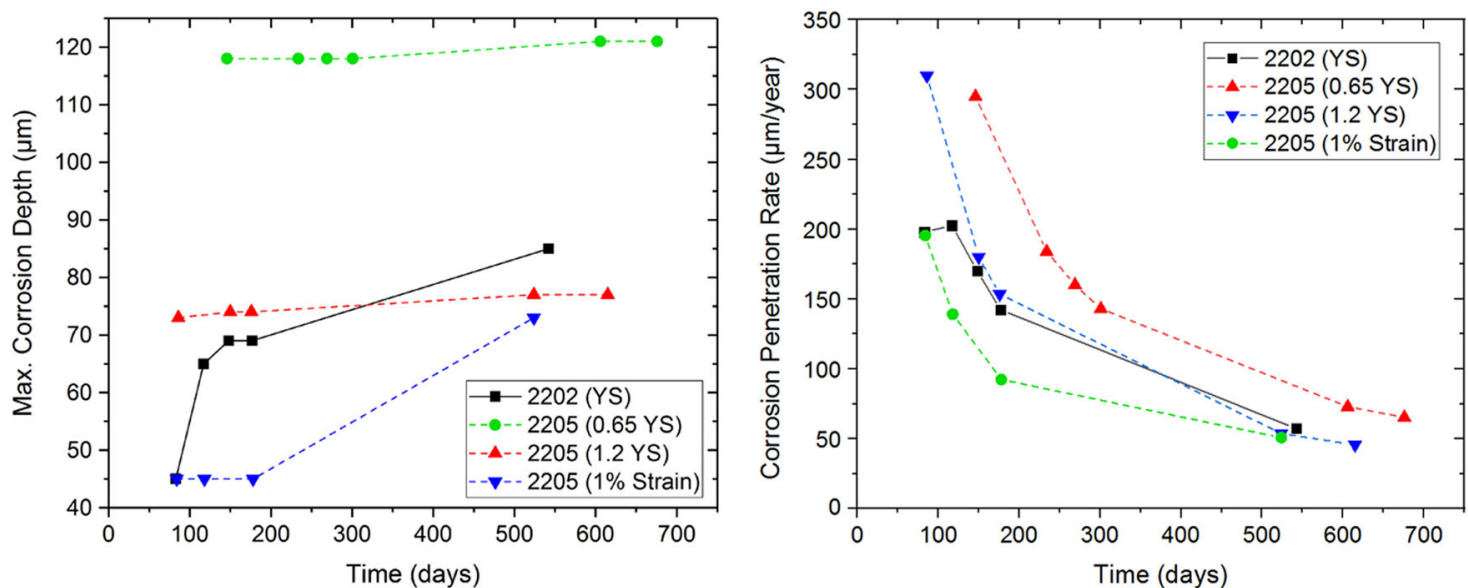

Fig. 7 Maximum corrosion depth (left) and corrosion penetration rate (right) determined by X-ray CT over time of 2202 and 2205 DSS after exposure to magnesium chloride at $50^{\circ} \mathrm{C}$ and $30 \% \mathrm{RH}$

The expansion of the area covered by surface corrosion indicates that the corrosion process in 2202 DSS can even expand to larger areas without the need for large net anodic current densities. Usually, large net anodic current densities are required to breakdown the passive layer of stainless steels, which is facilitated by large cathode-to-anode ratios under thin-film electrolytes and large cathodic kinetics due to abundant atmospheric oxygen reduction. ${ }^{57,58}$ Thus, the decrease of net-cathodic to net-anodic areas (actively corroded regions) would also mean a decrease of the CR. ${ }^{59}$ The CR increased rapidly in the first 4 months (Fig. 8), indicating a weak re-passivation behaviour. The initially discrete corrosion sites after 18 months of exposure linked up to a more widespread corroded area across the entire wire surface with exposure time, with the corrosion on the lean DSS grade progressing along the surface rather than in depth. This resulted in coalescence of different corrosion sites, forming one large connected area (Fig. 2d).

No cracks were observed by X-ray CT in the grade 2202 wire. However, post-mortem analyses revealed clear signs of SCC nuclei, showing that grade 2202 duplex wire is susceptible to chlorideinduced SCC under these conditions. The crack opening was a few microns, and hence below the current $X$-ray $C T$ resolution $(\approx 2 \mu \mathrm{m})$. Therefore, it remains unclear when these cracks started to develop. SCC can only occur when the crack velocity is higher or at a similar rate to the local $C R^{45,60,61}$
The longest crack observed in grade 2202 was approximately $80 \mu \mathrm{m}$. It is still a matter of debate whether an active corrosion site is required for crack nucleation, but SCC typically occurs after the initiation of corrosion. ${ }^{12,13,45}$ Experience on DSS has shown that in this environment corrosion typically initiates within 1-2 weeks. If one assumes the simultaneous occurrence of corrosion and SCC, a maximum SCC crack growth rate of $\approx 55 \mu \mathrm{m} /$ year can be estimated. However, the SCC rate is, like the $C R$, a parameter which changes over time, as demonstrated by Cook et al., ${ }^{13}$ who studied atmospheric-induced SCC behaviour on AISI 304 austenitic stainless steel at $40{ }^{\circ} \mathrm{C}$ using $\mathrm{MgCl}_{2}$ at its deliquescence point. In this study, SCC cracks were seen first after 2 months, with cracks growing up to $2.5 \mathrm{~mm}$ in length. The crack length did not change linearly with the exposure time. DSS's have superior SCC resistance to austenitic grades; therefore, their crack velocity can be orders of magnitude lower than in their austenitic counterparts. Both grades showed similar crack lengths at comparable loading conditions and, therefore, it can be assumed that both duplex wires have comparative SCC propensities with similar crack velocities in the studied environment.

Grade 2205 DSS was more resistant to corrosion attack than grade 2202 wire. The development of the corroded surface area and dissolved volume also seemed to follow a near-linear relationship with the exposure time. In comparison with the leaner DSS grade, the standard grade 2205 duplex wire had far 

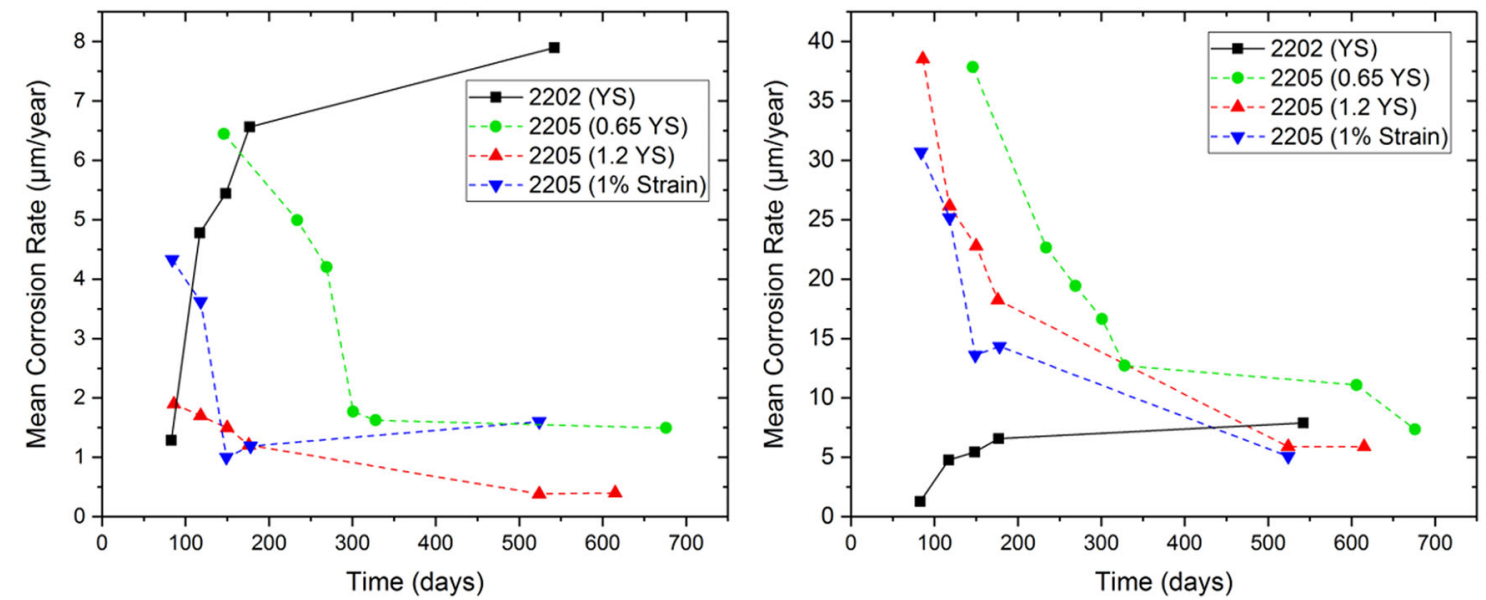

Fig. 8 Mean CRs determined by X-ray CT over time of 2202 and 2205 DSS after exposure to magnesium chloride at $50{ }^{\circ} \mathrm{C}$ and $30 \% \mathrm{RH}$, if (left) the surface area of the wire of the scanned volume is considered, with (right) if the surface area of only the corroded sites along the wire surface is corroded
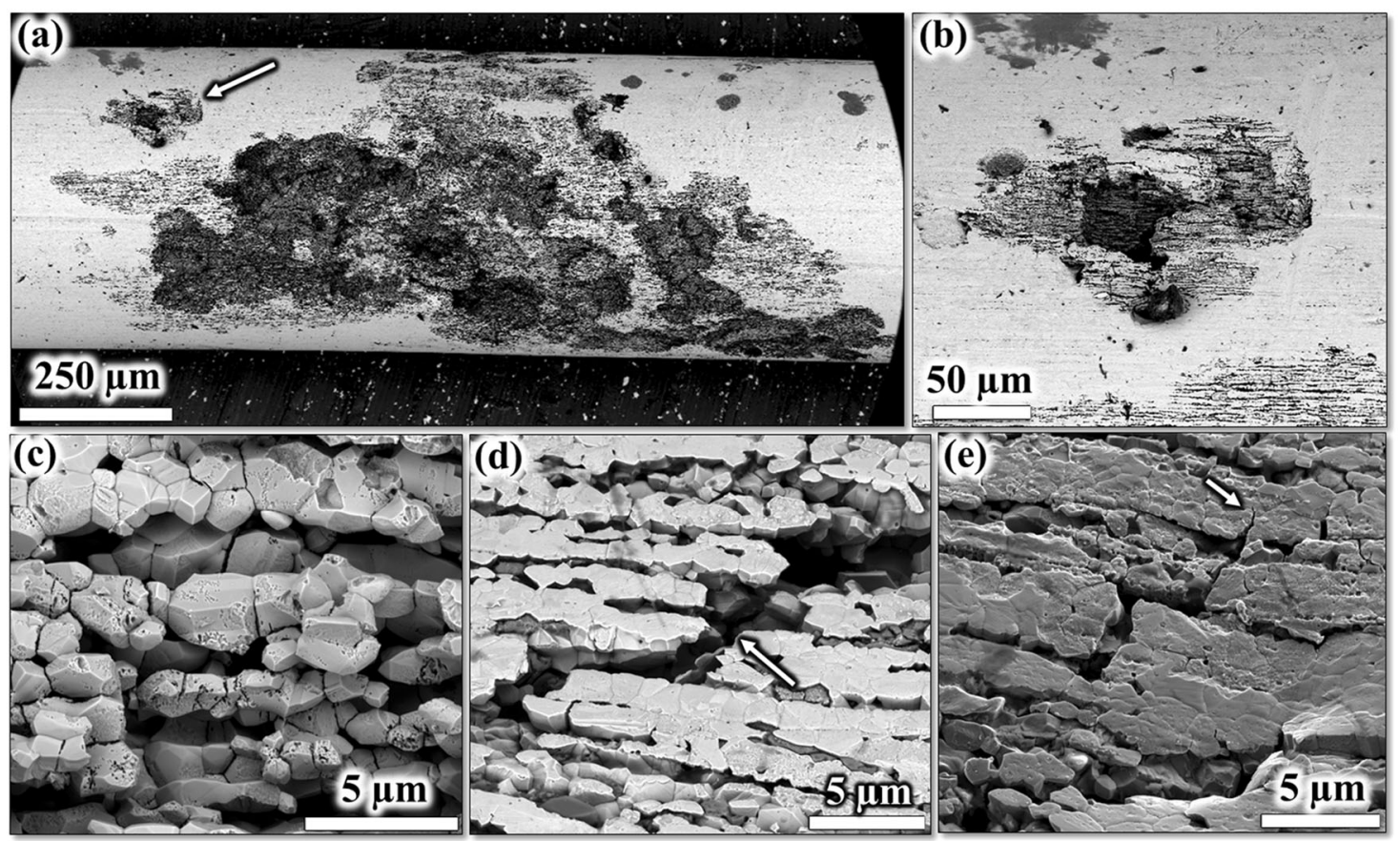

Fig. 9 Corrosion morphology of 2202-1 (YS) wire after 542 days of exposure: a general overview of a corroded area, b localised corrosion region shown by the arrow in a, $\mathbf{c}$ intergranular and pitting-like attack, $\mathbf{d}$ selective corrosion with an open crack (indicated by the arrow), e SCC crack nuclei at the surface a-d BSE-SEM images and e SE-SEM image

more corrosion sites, often in the form of discrete corrosion pits, but in terms of surface area, more corrosion was observed on the lean 2202 wire. The CRs for all grade 2205 wires were higher than grade 2202 DSS during the first 3-4 months. Strain clearly affected the susceptibility to localised corrosion of grade 2205 DSS since more discrete localised corrosion sites were seen with increasing strain. However, strain seemed to be beneficial since lower maximum corrosion depths and decreasing penetration rates were seen on grade 2205 with increasing magnitude of applied strain. In earlier work the effect of strain on atmospheric corrosion was elucidated, ${ }^{33}$ with macroscopic plastic deformation resulting in the development of local strain hot-spots, which were correlated to local Volta potential differences, indicating enhanced localised corrosion susceptibility. The austenite was more susceptible to localised corrosion than the ferrite, due to the development of local strain hot-spots. ${ }^{33}$ The reason for lower corrosion depths for strained wires is most-likely due to the decreased driving force for micro-galvanic interactivity between ferrite and austenite. The Volta potential difference between ferrite and austenite was earlier demonstrated to decrease with the increase of strain. ${ }^{29,31,33}$ This can lead to a decrease of the cathode-toanode ratio and hence to a decreasing driving force deep pitting. Hence, the material corrodes more towards the surface with more localised corrosion sites occurring along the wire surface due to more defected passive film.

The reason for higher CRs within the first months of exposure is an artefact of the CR estimation procedure, which only takes the total volume and the corroded area from X-ray CT data into consideration. Since the corrosion attack on the 2205 wires was highly localised, the total corroded area remained small, which resulted in higher CRs. However, the total volume and extent of corrosion was significantly lower than the damage observed on 

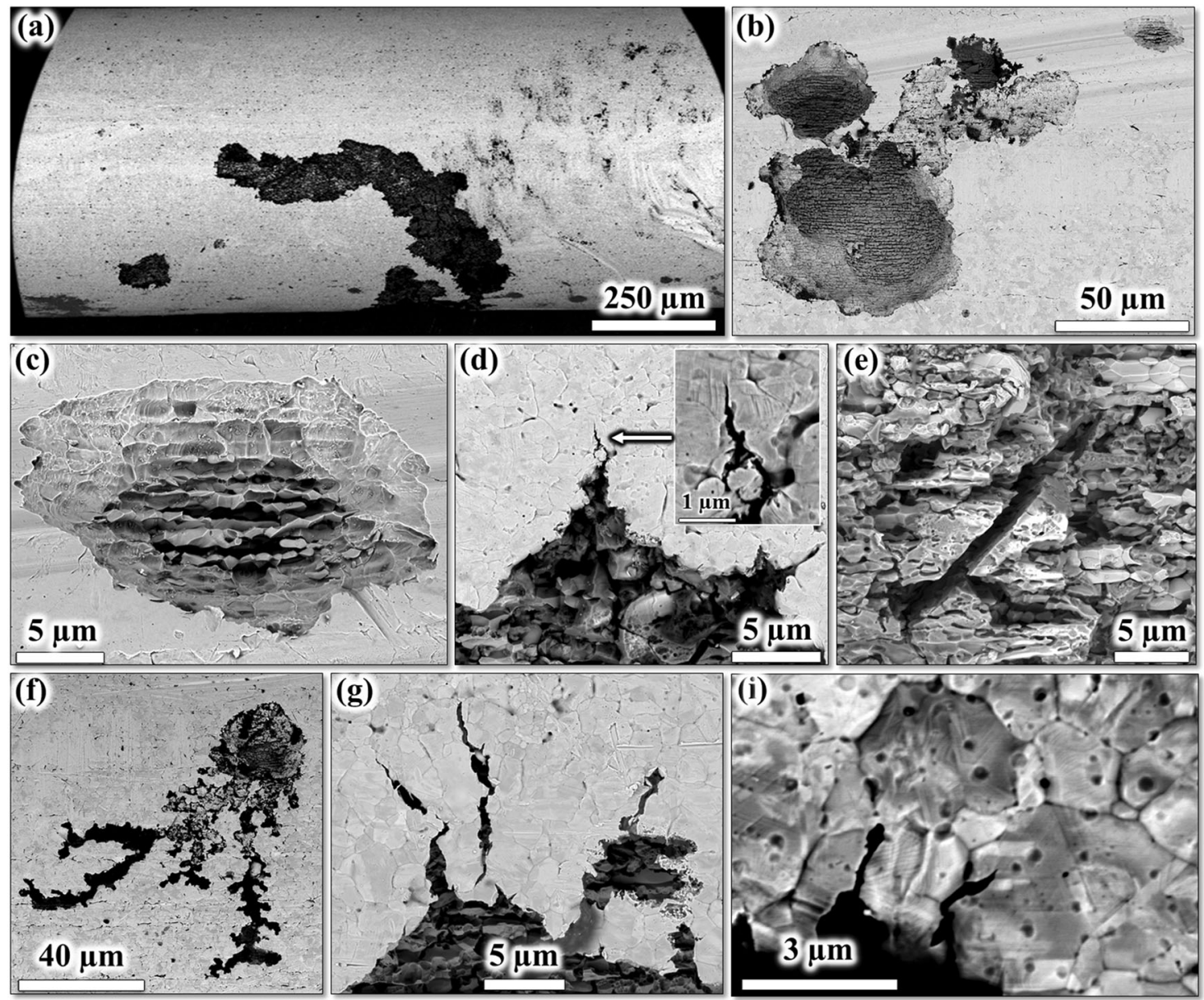

Fig. 10 Corrosion morphology of 2205-2 (0.65 YS) DSS wire after 615 days of exposure (BSE-SEM images): a general overview of the corroded region, $\mathbf{b}$ a few deep corrosion pits that seemed to have merged beneath the surface (lacy cover), $\mathbf{c}$ shallow corrosion site, indicating selective corrosion (most-likely of ferrite), $\mathbf{d}$ SCC crack nuclei adjacent to a corroded region, e transgranular crack within a localised corrosion site, $\mathbf{f}$ localised corrosion with filiform type undercut corrosion morphology, $\mathbf{g}$ SCC adjacent to a corroded region, $\mathbf{i}$ several sub-micrometre sized corrosion pits at exposed grain facets

lean 2202 wire, highlighting the superior corrosion resistance of grade 2205, associated with its higher $\mathrm{Ni}$ and Mo contents. The individual corrosion sites, however, as shown in Fig. 4b, c, seemed to have progressed more in depth, giving rise to undercut morphology. The corrosion process, which focuses on the largest anodic region located at the centre of the corrosion site shown in Fig. $4 b$, c, led to a more local corrosion pathway towards the centre of the wire. ${ }^{59}$ However, the corrosion process still seemed to be microstructurally influenced, with dissolving ferrite grains at the bottom of these sites, enabling corrosion growth along the wire drawing direction.

The observation of discrete corrosion pits in grade 2205 is a sign of stronger passivation behaviour, with corrosion only occurring at confined regions. Some of these discrete sites had a pit-like morphology (Fig. 11), possibly re-passivating before they could grow to a size where pits could sustain stable growth. In contrast, some of these sites grew deeper, also showing signs of selective attack. The area and depth of corrosion increased with longer exposure, but the overall CR decreased over time, as can be seen in Fig. 7. The volume of the larger corrosion sites did not increase significantly, but new sites were formed. These new sites had similar CRs as the larger site at the start of the experiment, as can be seen in Fig. 4d-f.

The crack shown in Fig. 9d was not observed after 177 days of exposure. This might suggest that this crack was not yet present, or the crack was below the $\mathrm{X}$-ray $\mathrm{CT}$ resolution limit $(<2-3 \mu \mathrm{m}$ in opening). Nonetheless, for both cases it is clear that this material has very low crack growth kinetics. The longest surface crack was $80-100 \mu \mathrm{m}$ long, oriented perpendicular to the wire loading direction.

Corrosion occurred heterogeneously for strained DSS, ${ }^{33}$ potentially causing the development of more local anodes, increasing the anode-to-cathode areas. The application of strain typically leads to an enhancement of the corrosion potential, but the critical pitting potential drops with increasing level of plastic strain. ${ }^{62} \mathrm{~A}$ loss of the re-passivation behaviour associated with plastic strain has also been reported. ${ }^{62}$ This might be the reason for the lower corrosion attack of the strained 2205 duplex wires.

Grade 2205 seemed to be more prone to distinct localised corrosion than lean 2202 DSS. Figure 10d shows localised corrosion sites from which branched corrosion paths seemed to have developed. Several small corrosion pits were seen decorating grain interiors and grain boundaries. Some micro-cracks developed from these localised corrosion sites, shown in Fig. 10e. The corrosion pits are most-likely associated with local strain heterogeneities, as characterised in earlier work, ${ }^{33}$ and are located at slip planes and triple junctions. The applied strain obviously favoured pitting and SCC on grade 2205. The maximum surface crack length measured perpendicular to the loading direction was $15-20 \mu \mathrm{m}$.

Both duplex wires showed localised corrosion sites with a perforation-like appearance which is reminiscent of lacy cover 

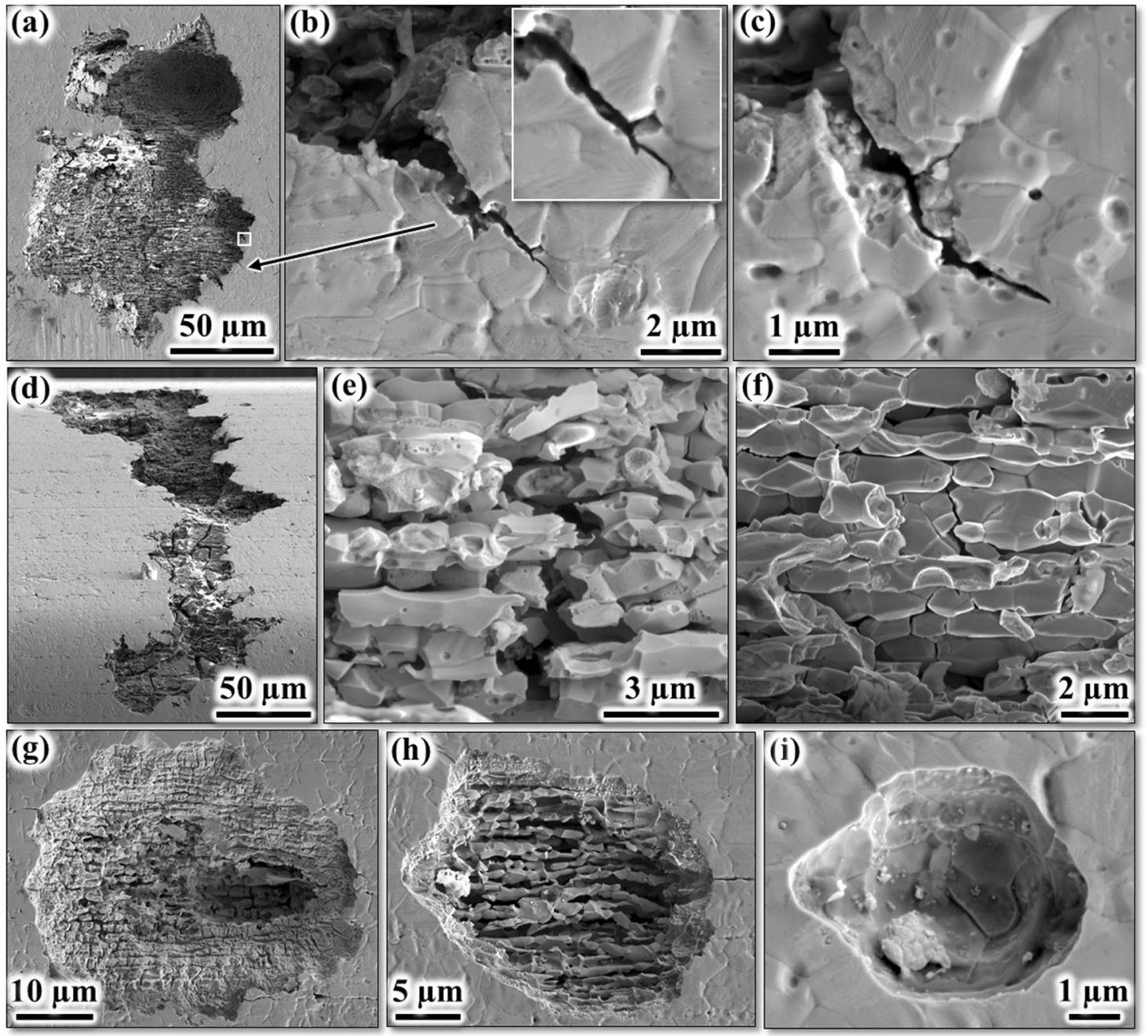

Fig. 11 Corrosion morphology of 2205-3 DSS (1.2 YS) wire after 524 days exposure: a a localised corrosion site with b-c showing transgranular SCC, $\mathbf{d}$ an elongated localised corrosion site with e-f showing the selective dissolution of either the ferrite or austenite within these sites. Narrow SCC cracks were observed at the bottom of those sites, $\mathbf{g}-\mathbf{h}$ indicating corrosion by selective attack, $\mathbf{i}$ showing a corrosion pit with no sign of selective corrosion. a-e, $\mathbf{g}-\mathbf{i}$ BSE-SEM images and $\mathbf{f}$ SE-SEM image

pitting, ${ }^{32,63}$ as shown in Fig. 9a, b, Fig. 10b, and Fig. 11a. The mechanism and evolution stages have been described by Ernst et al. ${ }^{63}$ Lacy cover pitting typically occurs in aqueous corrosion exposure and has often been observed on austenitic stainless steels. ${ }^{63-66}$ It was earlier demonstrated that lacy cover pitting is also possible on DSS under atmospheric conditions. ${ }^{32}$ It may be assumed that these lacy-cover-pit sites could develop in aqueoussimilar conditions. The volume of water depends on the $\mathrm{RH}$ and the amount of salt present on the surface of the wire. Experience showed that the deposited salt typically spreads heterogeneously over the surface and forms locally varying electrolyte thicknesses. Therefore, the deposition density approach to describe the quantity of the deposited salt is a guide value only. Hence, regions containing higher amounts of salt can accumulate more water, resulting in corrosion pits similar to those observed under immersed conditions.

It should be noted that the effect of removing samples from the humidity chamber may have slightly affected the measured CRs, since humidity changes can affect local growth of corrosion active sites. Associated corrosion reactions may have dropped to lower rates during this period, since the temperature during the $\mathrm{X}$-ray $\mathrm{CT}$ scans did not exceed $20^{\circ} \mathrm{C}$, compared to exposure in the humidity chamber at $50{ }^{\circ} \mathrm{C}$
Final remarks

The approach shown in this work has clearly demonstrated that CRs obtained by classic electrochemical techniques can be augmented by time-lapse, in situ X-ray CT observations for a thorough characterisation of the corrosion resistance of an alloy. Moreover, the corrosion propagation in 3D space may be important to know especially for applications, such as storage of ILW, where leakage can be a concern through materials with low wall-thicknesses. Therefore, in situ X-ray CT measurements can provide reliable information to assess the life-time performance of materials which conventional electrochemical or post-mortem analyses may not do. X-ray $\mathrm{CT}$, furthermore, can be considered complementary to conventional electrochemical analyses. Quantitative data obtained by X-ray CT could be used for simulation purposes to predict the structural integrity of materials.

It was further demonstrated that the quantification and visualisation of corrosion may be crucial in characterising the corrosion resistance of stainless steels. The CRs obtained from corrosion volume of weight loss data may not be sufficient to estimate long-term corrosion behaviour, in particular under atmospheric exposure conditions. 3D characterisation of corrosion in both quantity and morphology may be needed to assess the life time of structural components such as ILW containers and 

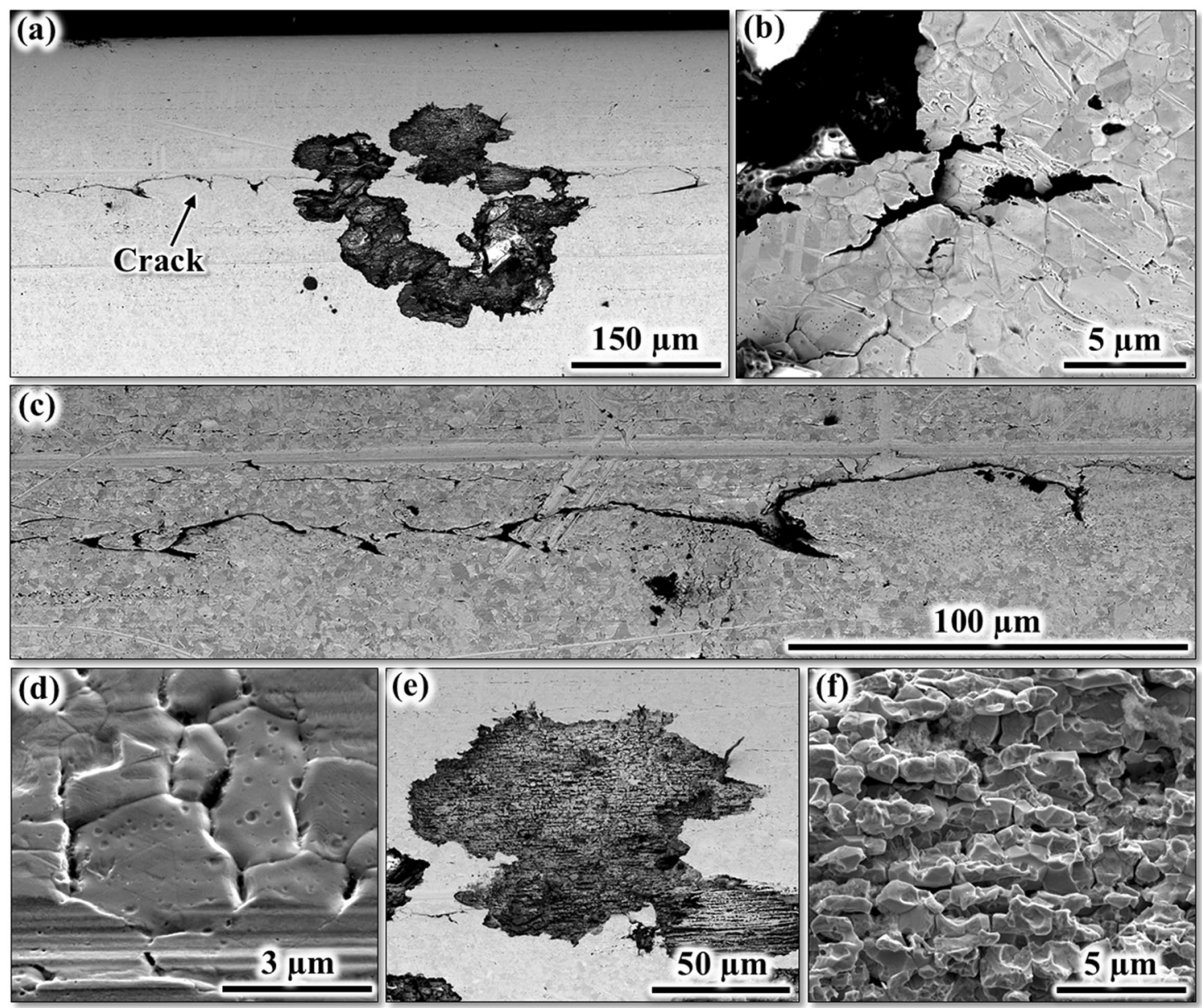

Fig. 12 Corrosion morphology of 2205-4 (1\%) DSS wire after 524 days exposure: a a localised corrosion site and a crack orientated parallel to the loading direction, $\mathbf{b}$ intergranular and transgranular SCC at the periphery of the corrosion site shown in $\mathbf{a}, \mathbf{c}$ a magnified view of the crack shown in a, $\mathbf{d}$ showing intergranular attack, $\mathbf{e - f}$ a localised corrosion site with the bottom indicating selective corrosion. a-c, e BSE-SEM images and $\mathbf{d}$, $\mathbf{f}$ SE-SEM image

therefore parameters such as corrosion depth, penetration rate, surface corrosion area, corrosion volume, and local CR etc. should be all scrutinised in detail.

It should be noted that the chosen wire material may not reflect the true processing nature of forged products which can have different residual stresses and slightly varying microstructures. Therefore, the CRs of a real container material, made from forged DSS, may be different from those reported in this work.

Time-lapse, in situ X-ray CT analysis of grade 2202 and 2205 DSS wires, exposed to $\mathrm{MgCl}_{2}$ atmospheric environment, led to the following conclusions:

1. Both grades were susceptible to localised corrosion, with selective dissolution of the ferrite phase playing a vital role in the corrosion propagation process.

2. Corrosion of grade 2205 was more localised and occurred preferentially in depth, whereas corrosion of grade 2202 was predominantly along the wire surface, yielding larger surface corrosion volumes and areas.

3. The CR of grade 2202 increased with time, whereas the CR for grade 2205 rapidly decreased.

4. Near-linear growth behaviour of corroded surface area and dissolved volume over time was observed for both wires, with grade 2205 showing superior corrosion resistance to grade 2202.

5. Atmospheric chloride-induced SCC was found in both DSS's, with similar crack lengths reaching up to $100 \mu \mathrm{m}$ in depth.
6. Lacy cover pitting corrosion has been observed in both steels. 7. Strain was seen to increase the resistance of grade 2205 to localised corrosion penetration but increased the number of local corrosion sites, resulting in preferred corrosion along the wire surface.

\section{METHODS}

Grade 2202 and 2205 DSS wires of 500 and $630 \mu$ m diameter, respectively, were used in this work. The 2202 and 2205 duplex wires had a yield strength of 700 and $850 \mathrm{MPa}$, respectively. The wires were solutionannealed at $1050^{\circ} \mathrm{C}$ by the manufacturer. The chemical composition of both wires is summarised in Table 1. The microstructure of both wires was metallographically assessed in both the drawn/extruded and transverse direction. For this, the wires were embedded in a cold mounting epoxy resin and ground and polished to $1 / 4 \mu \mathrm{m}$ diamond paste finish. The wires were then anodically etched using $40 \mathrm{wt} . \% \mathrm{KOH}$ at $5 \mathrm{~V}$ for a few seconds, which preferentially stains the ferrite phase..$^{31,67}$ The microstructure was analysed in an SEM using 10-20 kV with a spot size of 3-4, and secondary electron (SE) and backscattered electron (BSE) images are reported here.

The design of the in situ cell used for the atmospheric exposure of the wire samples is shown in Fig. 13. Strain was applied to investigate the susceptibility of the wires to AISCC. The applied strain was calibrated based on stress vs. strain measurements of a metal ring connected to the wire. A strain gauge was placed on the nappe of the ring, with load applied using a tensile testing machine. The ring, attached to a rod, was fixed in the tensile testing machine and elastically loaded in increments. The force on the ring, obtained from the tensile testing machine, and the corresponding 
Table 1. Chemical composition of the DSS wire materials used (in weight-\%)

\begin{tabular}{|c|c|c|c|c|c|c|c|c|c|c|c|c|}
\hline Grade & Name & $C$ & $\mathrm{Si}$ & $\mathrm{Mn}$ & $P$ & $S$ & $\mathrm{Cr}$ & $\mathrm{Ni}$ & Mo & $\mathrm{N}$ & $\mathrm{Cu}$ & $\mathrm{Fe}$ \\
\hline 2205 & UGI 4462 & $\leq 0.03$ & 0.8 & $1-2$ & $\leq 0.035$ & $\leq 0.01$ & $22-23$ & $5-6$ & 3.2 & $0.12-0.20$ & - & bal. \\
\hline 2202 & UGI 4042 & $\leq 0.03$ & $\leq 1.0$ & $\leq 2.0$ & $\leq 0.4$ & $\leq 0.01$ & $22.0-23.8$ & $2.0-2.8$ & $\leq 0.45$ & 0.155 & $\leq 0.5$ & bal. \\
\hline
\end{tabular}
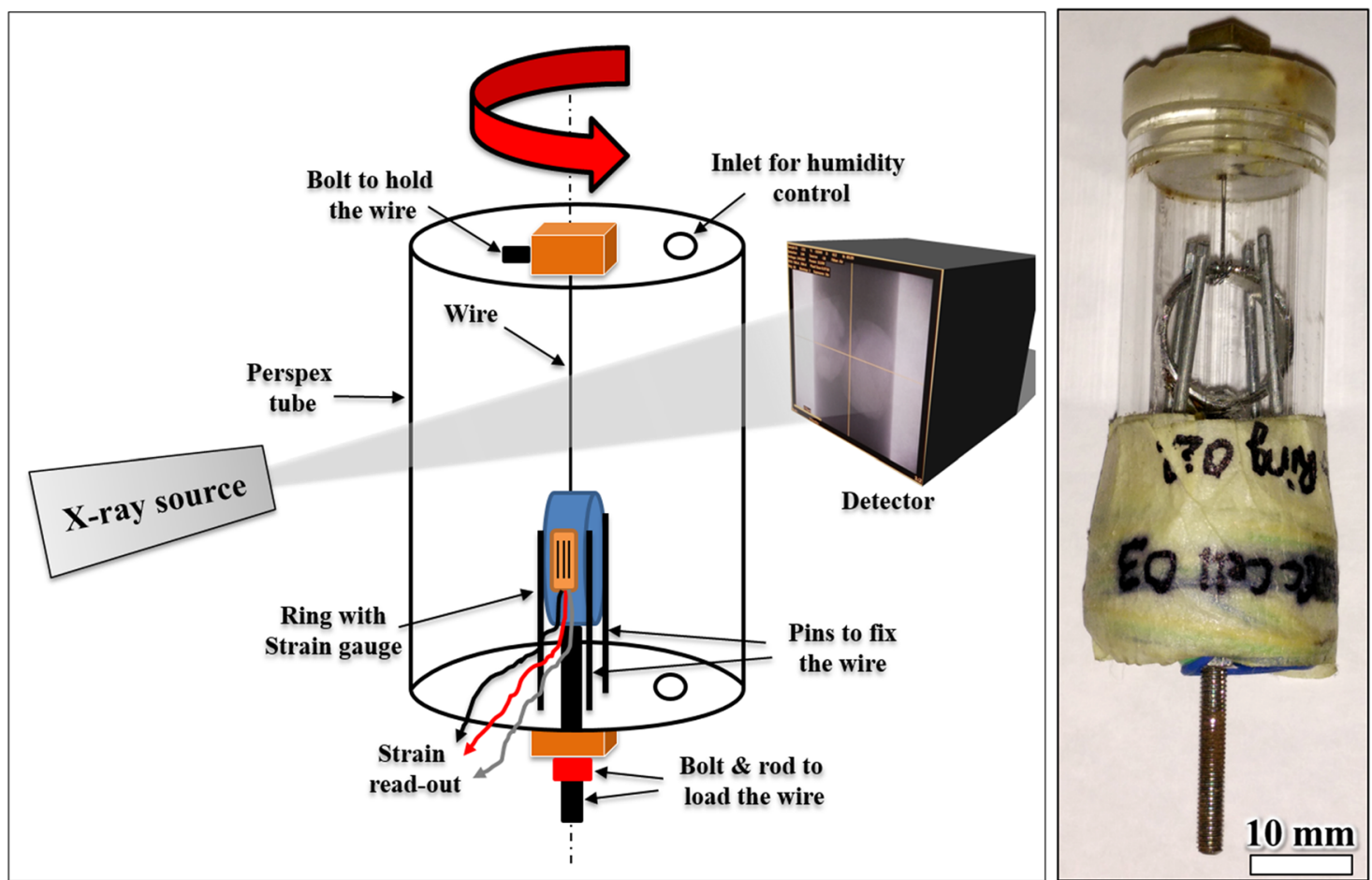

Fig. 13 Schematic illustration of the corrosion cell (left) and a corresponding photograph (right)

strain, obtained from a quarter-bridge strain gauge module, was recorded for each load increment.

For the in situ tests, the wires were placed in the corrosion cell, and the load manually applied by tightening the bolts (see Fig. 13) until the anticipated stress was reached, as determined from the strain gauge reading (constant load). Four identical in situ cells were constructed. Three cells contained grade 2205 wires and one grade 2202 wire, each loaded to different levels of strain. All the exposure conditions are summarised in Table 2.

\section{Corrosion testing}

The in situ corrosion cells were then briefly immersed in $1 \mathrm{M} \mathrm{MgCl}_{2}$ aqueous solution at room temperature, until the wire was totally covered, with the aim to contaminate the surface of the wire with the electrolyte. The cell was then removed from the electrolyte, dried and placed in a Binder KBF climatically controlled humidity chamber which was set to $50 \pm$ $1{ }^{\circ} \mathrm{C}$ and $30 \pm 3 \% \mathrm{RH}$. Usually, under this condition, a thin electrolyte film of $50-300 \mu \mathrm{m}$ with chloride concentrations of $12-15 \mathrm{M}$ and $\mathrm{pH} \sim 5$ forms. ${ }^{1,32,68}$ The electrolyte film was assumed to be homogenously covering the contaminated surface. However, the development of more discrete patches of chloride may have occurred during long-term exposure, in particular with periodic removal of the in situ cell from the humidity chamber. The surfaces of all exposed wire samples were inspected visually for corrosion damage before exposure, and all were initially free of any observable corrosion damage.

Holes on both sides of the in situ cells allowed humidity and temperature conditioning of the cell interior. For the time-lapse in situ X-ray CT scans, the cells were taken out from the humidity chamber after pre-defined time intervals, and scanned to assess the progression of corrosion attack. The cells were removed on the day of each scan, transferred to the CT scanner, and later on the same day or, if scanned overnight, during the next day, placed back into the humidity chamber for further controlled exposure. X-ray CT scans were carried out after 3, 4, 5, 6, $8,9,11,17,18,20$ and 21 months of exposure.

\section{X-ray computed tomography}

$\mathrm{X}$-ray CT scans were performed with a high resolution X-ray microscope at the Manchester X-ray Imaging Facility (MXIF). The scan parameters were $145 \mathrm{kV}$ source voltage, $15 \mathrm{~s}$ exposure time per projection, $4 \times$ objective lens, $10 \mathrm{~W}$ source power, and $2 \times 2$-pixel binning, providing an initial voxel resolution of $1 \mu \mathrm{m}$. For each scan, either 1601 or 2401 projections with a $360^{\circ}$ full rotation were acquired. The field of view (FOV) was approximately $1 \times 1 \mathrm{~mm}$. Centre shift and beam hardening coefficient adjustments were applied to improve the signal to noise ratio. All reconstructed data were analysed using Avizo 8.0 software. A median filter was applied for data smoothing, and the final voxel resolution was therefore close to $2 \mu \mathrm{m}$.

The corroded surface area of the wire and volume of dissolved material for each data set was determined by min./max. threshold segmentation. ${ }^{19,69}$ The corroded surface area of the wire was normalised by dividing the determined corrosion area by the total scanned area of the wire surface to compensate for different volumes/areas of wires to compare with different scans. The normalised corrosion volume was obtained by dividing the lost volume by the total measured volume of the wire. The mean CR of each wire was calculated in two ways by considering the volume of material loss, divided by either (i) the surface area of the wire of the scanned volume, or (ii) the surface area of only the corroded sites along the wire surface. The first approach provides a CR of the X-ray CT wire volume, but this also captures regions that are not corroded. The second approach (ii) gives the CR of only the corroded regions, which is more representative of $C R$ measurements for uniform corrosion behaviour. 
Table 2. Determined chloride deposition densities, segmented crack length, and estimated crack growth

\begin{tabular}{|c|c|c|c|c|c|c|c|}
\hline Sample & $\begin{array}{l}\text { Applied load } \\
(\mathrm{MPa})\end{array}$ & Strain & $\begin{array}{l}\text { Mean chloride deposition } \\
\text { density }\end{array}$ & $\begin{array}{l}\text { Mean corrosion rate } \\
(\mu \mathrm{m} / \text { year })\end{array}$ & $\begin{array}{l}\text { Max. crack } \\
\text { length } \\
(\mu \mathrm{m})\end{array}$ & $\begin{array}{l}\text { Mean crack growth } \\
\text { rate } \\
(\mu \mathrm{m} / \text { year) }\end{array}$ & Exposure (days) \\
\hline $2205-2$ & 550 & $65 \%$ Yield & $88 \mu \mathrm{g} / \mathrm{cm}^{2}$ & 7 & $\approx 100^{a}$ & 53 & 676 \\
\hline $2205-3$ & 900 & $120 \%$ Yield & $58 \mu \mathrm{g} / \mathrm{cm}^{2}$ & 5 & $\approx 100^{\mathrm{b}}$ & 69 & 615 \\
\hline $2205-4$ & 930 & $1 \%$ Strain & $63 \mu \mathrm{g} / \mathrm{cm}^{2}$ & 6 & $>1000^{b}$ & $>690$ & 524 \\
\hline
\end{tabular}

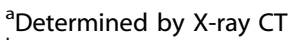

${ }^{b}$ Determined by SEM. Crack length determined by X-ray CT are in depth whereas those determined by SEM are superficial

All CRs values are then normalised to 365 days of exposure ( $\mu \mathrm{m} / \mathrm{year})$ :

Corrosion rate $=\frac{\text { Corrosion volume }\left[\mu \mathrm{m}^{3}\right]}{\text { Surface area }\left[\mu \mathrm{m}^{3}\right]} \times \frac{365[\text { days } / \text { year }]}{\text { Exposure[days }]}$

All observed corrosion was localised, and therefore, the mean $\mathrm{CR}$ reflects in the strict sense the averaged localised CR. The CR may further be perceived as a measure for the penetration of the wire. Localised corrosion towards the depth of the wire was further quantified using the parameter 'penetration rate', being defined as:

Corrosion penetration rate $=$ Maximum corrosion $\operatorname{depth}[\mu \mathrm{m}] \times \frac{365[\text { days } / \text { year }]}{\text { Exposure[days }]}$

The corrosion penetration rate may be used to assess the life time of thin-walled structures such as ILW containers.

\section{Chloride analysis}

The chloride deposition densities for all wires were determined using ion chromatography (IC). For this, the wires were removed from the corrosion cells after tests were terminated and then immersed in $10 \mathrm{wt} . \%$ citric acid solutions at $\approx 80^{\circ} \mathrm{C}$ for $48 \mathrm{~h}$. Earlier examinations showed that no metal attack occurred when DSS was exposed for several days to $10 \mathrm{wt} . \%$ citric acid. $^{32}$ This electrolyte dissolves corrosion products and chlorides without attacking the underlying DSS microstructure.

A range of citric acid solution concentrations and chloride concentrations were used as calibration standards for IC for determination of the chloride level in each of the anolytes. The determined deposition densities are given in Table 2 . It should be noted that the local deposition densities may vary across the surface, since the corrosion products were only formed at certain sites and were not homogeneously distributed. Though, the mean deposition density gives an idea of the amount of salt present on those sample surfaces.

\section{Post-mortem SEM observation}

At the end of the experiment, the wires were rinsed with deionised water and dried using hot air. The corrosion morphology was examined in a high resolution SEM. The data reported were analysed after 541 and 615 days of exposure for the grade 2202 and grade 2205 DSS wires, respectively, with SEM images acquired to show the extent of corrosion attack and to correlate with X-ray CT observations.

\section{Data availability}

The data that support the findings of this study are available from the corresponding author upon reasonable request.

\section{ACKNOWLEDGEMENTS}

The authors acknowledge Radioactive Waste Management (RWM) (NPO004411AEPS02) and EPSRC (EP/I036397/1) for financial support for C.Ö. and D.L.E. The authors acknowledge the provision of beam time at Henry Moseley Manchester X-ray Imaging Facility (HMXIF) at the University of Manchester, UK, established with funding from EPSRC through grants EP/F007906, EP/I02249X and EP/F028431. The authors are grateful for the kind provision of both grades 2205 and 2202 duplex stainless steel wires by Ugitech, France. P.J.W. is grateful for a European Research Council for funding COREL-CT under grant No 695638. This work was funded by
Radioactive Waste Management (RWM) under the research grant no. NPO004411AEPSO2 and EPSRC under the grant no. EP/I036397/1. Some parts of the work was further funded by European Research Council under grant no. 695638.

\section{AUTHOR CONTRIBUTIONS}

C.Ö. planned and designed the experimental setup, performed all tests and analyses, analysed and evaluated all data, and wrote the manuscript. F.L. optimised the experimental setup, performed the experiments, and analysed the X-ray CT data. S.A $M$ optimised the experimental setup, performed the experiments, and analysed the X-ray CT data. A.P. analysed the X-ray CT data. P.J.W contributed to data analysis and manuscript preparation. D.L.E planned and designed the experimental setup, contributed to data analysis and manuscript preparation.

\section{ADDITIONAL INFORMATION}

Competing interests: The authors declare no competing financial interests.

Publisher's note: Springer Nature remains neutral with regard to jurisdictional claims in published maps and institutional affiliations.

\section{REFERENCES}

1. Prosek, T., Iversen, A., Taxen, C. \& Thierry, D. Low-temperature stress corrosion cracking of stainless steels in the atmosphere in the presence of chloride deposits. Corrosion 65, 105-117 (2009).

2. Prosek, T. et al. Low-temperature stress corrosion cracking of austenitic and duplex stainless steels under chloride deposits. Corrosion 70, 1052-1063 (2014).

3. Prosek, T., Iversen, A. \& Taxen, C. in NACE Vol. Paper No. 0848417 (NACE International, Houston, Texas, 2008).

4. Smart, N. R., Pritchard, A. M. \& Turnbull, A. Review of Environmental Conditions for Storage of ILW Radioactive Waste Containers 1-65 (Technical \& Assurance Services Serco Ltd, Abingdon, Oxfordshire, 2010).

5. King, F. Corrosion Resistance of Austenitic and Duplex Stainless Steels in Environments Related to UK Geological Disposal. Report No. QRS-1384C-R1 (Quintessa Ltd. in Henley-on-Thames, Oxfordshire, UK, 2009).

6. Kangas, P. \& Nicholls, J. M. Chloride-induced stress corrosion cracking of duplex stainless steels. Models, test methods and experience. Mater. Corros. 46, 354-365 (1995).

7. Davenport, A. J. et al. Mechanistic studies of atmospheric pitting corrosion of stainless steel for ILW containers. Corros. Eng. Sci. Technol. 49, 514-520 (2014).

8. Albores-Silva, O. E., Charles, E. A. \& Padovani, C. Effect of chloride deposition on stress corrosion cracking of $316 \mathrm{~L}$ stainless steel used for intermediate level radioactive waste containers. Corros. Eng. Sci. Technol. 46, 124-128 (2011).

9. Padovani, C., Albores-Silva, O. \& Charles, A. Corrosion control of stainless steels in indoor atmospheres-laboratory measurements under $\mathrm{MgCl}_{2}$ deposits at constant relative humidity (Part 1). Corrosion 71, 292-304 (2014).

10. Padovani, C. et al. Corrosion control of stainless steels in indoor atmospherespractical experience (Part 2). Corrosion 71, 646-666 (2014).

11. Padovani, C. Overview of UK research on the durability of container materials for radioactive wastes. Corros. Eng. Sci. Technol. 49, 402-409 (2014).

12. Cook, A. et al. in 18th International Corrosion Conference Vol. 2 1438-1449 (Perth, Australia, 2011).

13. Cook, A. B. et al. Preliminary evaluation of digital image correlation for in-situ observation of low temperature atmospheric-induced chloride stress corrosion cracking in austenitic stainless steels. ECS Trans. 25, 119-132 (2010). 
14. Cook, A. B., Gu, B., Lyon, S. B., Newman, R. C. \& Engelberg, D. L. Towards a more realistic experimental protocol for the study of atmospheric chloride-induced stress corrosion cracking in intermediate level radioactive waste container materials. MRS Online Proc. Libr. 1665, 225-230 (2014).

15. Cook, A. B. et al. Assessing the risk of under-deposit chloride-induced stress corrosion cracking in austenitic stainless steel nuclear waste containers. Corros. Eng., Sci. Technol. 49, 529-534 (2014).

16. Lyon, S. B., Steven, N. P. C., Cook, A. \& Duff, J. in Diamond'10 Conference Decommissioning, Immobilisation and Management of Nuclear Waste for Disposal (Manchester, UK, 2010).

17. Ghahari, S. M. et al. Pitting corrosion of stainless steel: measuring and modelling pit propagation in support of damage prediction for radioactive waste containers. Corros. Eng. Sci. Technol. 46, 205-211 (2011).

18. Ghahari, S. M. et al. In situ synchrotron X-ray micro-tomography study of pitting corrosion in stainless steel. Corros. Sci. 53, 2684-2687 (2011).

19. Almuaili, F. A., McDonald, S. A., Withers, P. J. \& Engelberg, D. L. Application of a quasi in situ experimental approach to estimate 3-D pitting corrosion kinetics in stainless steel. J. Electrochem. Soc. 163, C745-C751 (2016).

20. Marrow, T. J., Buffiere, J. Y., Withers, P. J., Johnson, G. \& Engelberg, D. High resolution X-ray tomography of short fatigue crack nucleation in austempered ductile cast iron. Int. J. Fatigue 26, 717-725 (2004).

21. Burnett, T. L. et al. Correlative tomography. Sci. Rep. 4, 4711 (2014).

22. Connolly, B. J. et al. X-ray microtomography studies of localised corrosion and transitions to stress corrosion cracking. Mater. Sci. Technol. 22, 1076-1085 (2006).

23. Prosek, T. et al. Duplex Stainless Steel in Storage Tanks (Duplextank). Report No. Final Report, 1-135 (Directorate-General for Research and Innovation, Directorate G-Industrial Technologies, Unit G.5-Research Fund for Coal and Steel, Brussels, European Commission in Brussels, Belgium, 2013).

24. Prosek, T. Material Classification for Climbing Anchors-phase 2: Development of an Anchor Classification and Related Test Procedure for the Evaluation of Stress Corrosion Cracking (Scc) and Corrosion Resistances of Climbing Anchors. Report No. Commission Report IC 88588, 1-27 (Institut de la Corrosion [French Corrosion Institute], Brest, France, 2014).

25. Arnold, N., Gümpel, P., Heitz, T. \& Pscheidl, P. Chloridinduzierte Korrosion von Nichtrostenden Stählen in Schwimmhallen-Atmosphären Teil 1: Elektrolyt Magnesium-Chlorid (30\%). Mater. Corros. 48, 679-686 (1997).

26. Arnold, N., Gümpel, P. \& Heitz, T. W. Chloridinduzierte Korrosion von nichtrostenden Stählen in Schwimmhallen-Atmosphären Teil 3: Einfluß einer realen Schwimmhallen-Atmosphäre. Mater. Corros. 50, 140-145 (1999).

27. Arnold, N., Gümpel, P. \& Heitz, T. W. Chloridinduzierte Korrosion von nichtrostenden Stählen in Schwimmhallen-Atmosphären Teil 2: Einfluß von Hypochloriten. Mater. Corros. 49, 482-488 (1998).

28. Örnek, C., Idris, S., Reccagni, P. \& Engelberg, D. Atmospheric-induced stress corrosion cracking of grade 2205 duplex stainless steel-effects of $475^{\circ} \mathrm{C}$ embrittlement and process orientation. Metals 6, 167 (2016)

29. Örnek, C. \& Engelberg, D. L. Towards understanding the effect of deformation mode on stress corrosion cracking susceptibility of grade 2205 duplex stainless steel. Mater. Sci. Eng. A 666, 269-279 (2016).

30. Örnek, C. \& Engelberg, D. L. Correlative EBSD and SKPFM characterisation of microstructure development to assist determination of corrosion propensity in grade 2205 duplex stainless steel. J. Mater. Sci. 51, 1931-1948 (2015).

31. Örnek, C. \& Engelberg, D. L. An experimental investigation into strain and stress partitioning of duplex stainless steel using digital image correlation, X-ray diffraction and scanning Kelvin probe force microscopy. J. Strain Anal. Eng. Des. 51, 207-219 (2016)

32. Örnek, C., Zhong, X. \& Engelberg, D. L. Low-temperature environmentally assisted cracking of grade 2205 duplex stainless steel beneath a $\mathrm{MgCl}_{2}: \mathrm{FeCl}_{3}$ salt droplet. Corrosion 72, 384-399 (2015).

33. Örnek, C. \& Engelberg, D. L. SKPFM measured Volta potential correlated with strain localisation in microstructure to understand corrosion susceptibility of cold-rolled grade 2205 duplex stainless steel. Corros. Sci. 99, 164-171 (2015).

34. Engelberg, D. L. \& Örnek, C. Probing propensity of grade 2205 duplex stainless steel towards atmospheric chloride-induced stress corrosion cracking. Corros. Eng., Sci. Technol. 49, 535-539 (2014).

35. Örnek, C. \& Engelberg, D. L. Eurocorr 2014 1-10 (European Federation of Corrosion, Pisa, 2014).

36. Örnek, C. \& Engelberg, D. L. Corrosion Management 9-11 (The Institute of Corrosion, Northampton, 2013).

37. Örnek, C, Ahmed, A. H. \& Engelberg, D. L. Eurocorr 2012 1-10 (Dechema, Istanbul, 2012).

38. Lynch, S. P. in Stress Corrosion Cracking (eds Raja, V. S. \& Shoji, T.) 3-89 (Woodhead Publishing Limited, Cambridge, UK, 2011).

39. Lee, J.-S., Fushimi, K., Nakanishi, T., Hasegawa, Y. \& Park, Y.-S. Corrosion behaviour of ferrite and austenite phases on super duplex stainless steel in a modified green-death solution. Corros. Sci. 89, 111-117 (2014).
40. Symniotis, E. Galvanic effects on the active dissolution of duplex stainless steels. Corrosion 46, 2-12 (1990).

41. Aoki, S., Ito, K., Yakuwa, H., Miyasaka, M. \& Sakai, Ji Potential dependence of preferential dissolution behavior of a duplex stainless steel in simulated solution inside crevice. Zair.-to-Kankyo 60, 363-367 (2011).

42. Aoki, S., Yakuwa, H., Mitsuhashi, K. \& Sakai, Ji Dissolution behavior of a and Y phases of a duplex stainless steel in a simulated crevice solution. ECS Trans. 25, 17-22 (2010).

43. Örnek, C. et al. Characterization of $475^{\circ} \mathrm{C}$ embrittlement of duplex stainless steel microstructure via scanning kelvin probe force microscopy and magnetic force microscopy. J. Electrochem. Soc. 164, C207-C217 (2017).

44. Morton, S. C. Atmospheric Pitting Corrosion of AA7075-T6 Under Evaporating Droplets (The Ohio State University, Ohio, US, 2013).

45. Cottis, B. et al. Shreir's Corrosion. Vol. 1 (eds Cottis, B. et al.) (Elsevier B.V., Manchester, 2010)

46. Jae-Ho, S. \& Jae-Bong, L. Critical pitting temperature of 2205 duplex stainless steels using immersion and electrochemical polarization test methods. J. Korean Inst. Surf. Eng. 39, 18-24 (2006).

47. Tsai, W.-T. \& Chen, J.-R. Galvanic corrosion between the constituent phases in duplex stainless steel. Corros. Sci. 49, 3659-3668 (2007).

48. Zhang, L. et al. Effect of aging on the corrosion resistance of 2101 lean duplex stainless steel. Mater. Charact. 60, 1522-1528 (2009).

49. Zhang, L. et al. Influence of annealing treatment on the corrosion resistance of lean duplex stainless steel 2101. Electrochim. Acta 54, 5387-5392 (2009).

50. Williams, D. E., Newman, R. C., Song, Q. \& Kelly, R. G. Passivity breakdown and pitting corrosion of binary alloys. Nature 350, 216-219 (1991).

51. Tsutsumi, Y., Nishikata, A. \& Tsuru, T. Pitting corrosion mechanism of Type 304 stainless steel under a droplet of chloride solutions. Corros. Sci. 49, 1394-1407 (2007)

52. Charles, J. \& Bernhardsson, S. in Duplex Stainless Steels ' 91 (eds J. Charles \& S. Bernhardsson) (Les éditions de physique, Les Ulis Cedex A, France, 1991).

53. Oldfield, D. J. W. Nickel effect: lower rate of corrosion in stainless. Emerald Group Publ. Ltd. 37, 9-11 (1990).

54. Potgieter, J. H., Olubambi, P. A., Cornish, L., Machio, C. N. \& Sherif, E.-S. M. Influence of nickel additions on the corrosion behaviour of low nitrogen $22 \% \mathrm{Cr}$ series duplex stainless steels. Corros. Sci. 50, 2572-2579 (2008).

55. Lu, Y. C., Ives, M. B. \& Clayton, C. R. Synergism of alloying elements and pitting corrosion resistance of stainless steels. Corros. Sci. 35, 89-96 (1993).

56. Mesquita, T. J., Chauveau, E., Mantel, M. \& Nogueira, R. P. A XPS study of the Mo effect on passivation behaviors for highly controlled stainless steels in neutral and alkaline conditions. Appl. Surf. Sci. 270, 90-97 (2013).

57. Cox, A. \& Lyon, S. B. An electrochemical study of the atmospheric corrosion of mild steel-I. Experimental method. Corros. Sci. 36, 1167-1176 (1994).

58. Li, S. \& Hihara, L. H. Atmospheric-Corrosion Electrochemistry of $\mathrm{NaCl}$ Droplets on Carbon Steel. J. Electrochem. Soc. 159, C461-C468 (2012).

59. Williams, G., Birbilis, N. \& McMurray, N. Controlling factors in localised corrosion morphologies observed for magnesium immersed in chloride containing electrolyte. Faraday Discuss. 180, 313-330 (2015).

60. Tsujikawa, S. Initiation of Cl-SCC Cracks from Crevices Rather than From Pits. (The Minerals, Metals \& Materials Society, Warrendale, Pennsylvania, US, 2001).

61. Cottis, R. A. \& Newman, R. C. Stre ss Corrosion Cracking Resistance of Duplex Stainless Steels. 58 (Health and Safety Executive, Manchester, UK, 1993).

62. Lu, G., Cheng, H., Xu, C. \& He, Z. Effect of strain and chloride concentration on pitting susceptibility for type 304 austenitic stainless steel. Chin. J. Chem. Eng. 16, 314-319 (2008).

63. Ernst, P., Laycock, N. J., Moayed, M. H. \& Newman, R. C. The mechanism of lacy cover formation in pitting. Corros. Sci. 39, 1133-1136 (1997)

64. Ernst, P., Moayed, M. H., Laycock, N. J. \& Newman, R. C. Pits and Pores: Formation, Properties, and Significance for Advanced Luminescent Materials. In Proc. International Symposium on Pits and Pores, (eds Schmuki P., Lockwood D. J., Isaacs H., Bsiesy A. 176 (The Electrochemical Society, Pennington, NJ, USA, 1997).

65. Laycock, N. J., Moayed, M. H. \& Newman, R. C. Metastable pitting and the critical pitting temperature. J. Electrochem. Soc. 145, 2622-2628 (1998).

66. Newman, R. C. 2001 W.R. Whitney award lecture: understanding the corrosion of stainless steel. Corrosion 57, 1030-1041 (2001).

67. Örnek, C., Burke, M. G., Hashimoto, T. \& Engelberg, D. L. 748 K $\left(475^{\circ} \mathrm{C}\right)$ Embrittlement of Duplex stainless steel: effect on microstructure and fracture behavior. Metall. Mater. Trans. A 48,1-13 (2017).

68. Tsutsumi, Y., Nishikata, A. \& Tsuru, T. Initial stage of pitting corrosion of type 304 stainless steel under thin electrolyte layers containing chloride ions. J. Electrochem. Soc. 152, B358-B363 (2005).

69. Almuaili, F. A., McDonald, S. A., Withers, P. J., Cook, A. B. \& Engelberg, D. L. Straininduced reactivation of corrosion pits in austenitic stainless steel. Corros. Sci. 125, 12-19 (2017). 
Open Access This article is licensed under a Creative Commons Attribution 4.0 International License, which permits use, sharing, adaptation, distribution and reproduction in any medium or format, as long as you give appropriate credit to the original author(s) and the source, provide a link to the Creative Commons license, and indicate if changes were made. The images or other third party material in this article are included in the article's Creative Commons license, unless indicated otherwise in a credit line to the material. If material is not included in the article's Creative Commons license and your intended use is not permitted by statutory regulation or exceeds the permitted use, you will need to obtain permission directly from the copyright holder. To view a copy of this license, visit http://creativecommons. org/licenses/by/4.0/.

(c) The Author(s) 2018 